\title{
Characterizing Antimicrobial Use in the Livestock Sector in Three South East Asian Countries (Indonesia, Thailand, and Vietnam)
}

\author{
Lucy Coyne ${ }^{1, *}$, Riana Arief ${ }^{2}$, Carolyn Benigno ${ }^{3}$, Vo Ngan Giang ${ }^{4}$, Luu Quynh Huong ${ }^{5}$, \\ Saharuetai Jeamsripong ${ }^{6}$, Wantanee Kalpravidh ${ }^{3}$, James McGrane ${ }^{7}$, Pawin Padungtod ${ }^{4}$, \\ Ian Patrick ${ }^{1,8}$, Luuk Schoonman ${ }^{7}$, Erry Setyawan ${ }^{7}{ }^{\circledR}$, Ady Harja Sukarno ${ }^{7}$, Jutanat Srisamran ${ }^{6}$, \\ Pham Thi Ngoc ${ }^{5}$ and Jonathan Rushton ${ }^{1}$ \\ 1 Epidemiology and Population Health, University of Liverpool, Neston CH64 7TE, UK; \\ ianpatrick4229@gmail.com (I.P.); J.Rushton@liverpool.ac.uk (J.R.) \\ 2 Center for Indonesian Veterinary Analytical Studies, Bogor 16310, Indonesia; rianaarief83@gmail.com \\ 3 FAO Regional Office for Asia and the Pacific, Bangkok 10200, Thailand; carolynbenigno@gmail.com (C.B.); \\ Wantanee.Kalpravidh@fao.org (W.K.) \\ $4 \quad$ FAO Country Office for Vietnam, Hanoi, Vietnam; Ngangiang.Vo@fao.org (V.N.G.); \\ Pawin.Padungtod@fao.org (P.P.) \\ 5 National Institute of Veterinary Research, Hanoi, Vietnam; lqhuongvet@yahoo.com (L.Q.H.); \\ minhngoc27169@gmail.com (P.T.N.) \\ 6 Department of Veterinary Public Health, Faculty of Veterinary Science, Chulalongkorn University, \\ Bangkok 10330, Thailand; Saharuetai.J@chula.ac.th (S.J.); jutanatmilk@hotmail.com (J.S.) \\ 7 FAO Country Office for Indonesia, Jakarta 10250, Indonesia; James.McGrane@fao.org (J.M.); \\ luuk.schoonman@gmail.com (L.S.); erry.setyawan@gmail.com (E.S.); adiharja@gmail.com (A.H.S.) \\ 8 Agricultural and Resource Economic Consulting Services, Armidale, NSW 2350, Australia \\ * Correspondence: 1.a.coyne@liverpool.ac.uk
}

Received: 31 January 2019; Accepted: 15 March 2019; Published: 25 March 2019

\begin{abstract}
A framework was developed to characterize the antimicrobial use/antimicrobial resistance complex in livestock systems in Indonesia, Vietnam, and Thailand. Farm profitability, disease prevention, and mortality rate reduction were identified as drivers toward antimicrobial use in livestock systems. It revealed that antimicrobial use was high in all sectors studied, and that routine preventative use was of particular importance to broiler production systems. Misleading feed labeling was identified as a hurdle to the collection of accurate antimicrobial use data, with farmers being unaware of the antimicrobials contained in some commercial feed. Economic analysis found that the cost of antimicrobials was low relative to other farm inputs, and that farm profitability was precariously balanced. High disease and poor prices were identified as potential drivers toward economic loss. The research indicates that antimicrobial use in small-scale poultry production systems improves feed conversion ratios and overall productivity. However, data were limited to quantify adequately these potential gains and their impacts on the food supply. During the study, all countries embraced and implemented policies on better management of antimicrobial use in livestock and surveillance of antimicrobial resistance. Future policies need to consider farm-level economics and livestock food supply issues when developing further antimicrobial use interventions in the region.
\end{abstract}

Keywords: antimicrobial; antibiotic; antimicrobial resistance; antimicrobial use; economics; Vietnam; Indonesia; Thailand; framework; policy 


\section{Introduction}

Antimicrobial Resistance as a One Health Challenge

There has been a continual increase in the human population from 2.5 billion in 1960 to 7.53 billion in 2017 with growth projected to reach 10 billion by 2050. Much of the future population expansion is predicted to be in low income and middle income countries (LMICs) [1,2]. In parallel, there has been increasing urbanization with a greater proportion of the global population now residing in urban areas [3]. This transition has been linked, in part, with rising household incomes and is accompanied with growing demand for animal source proteins [4].

The increasing demand for animal source proteins has been met through a global shift toward more intensive livestock production systems with a focus on the monogastric species (predominantly pigs and poultry). These systems rely heavily on the availability of cheap feed grains and oilseed cake, which are in limited supply in some LMICs. This raises doubts over the economic sustainability of such a food system approach. Highly integrated and intensive production systems require antimicrobials to ensure animal health and maintain productivity and profitability. Thus, alongside this intensification of livestock production, there has been an accompanying increase in antimicrobial consumption and a consequential increase in antimicrobial resistance (AMR) [5].

The global concerns over AMR are well documented with Lord O'Neill estimating a potential human mortality in the region of 10 million by 2050 with an accompanying economic burden of 100 trillion USD [6]. AMR has its origin in the unregulated use of antimicrobials in the human health, veterinary medicine, and production sectors. This use exerts selection pressure on pathogen populations that encourage the development of resistance and exchange of resistance genes. The threat AMR poses to human and animal health has resulted in growing international pressure to minimize the prescribing of antimicrobials and ensure that use is prudent in both human and veterinary medicine [7-10].

The zoonotic pathways for the spread of resistance from organisms existing within animal populations to those of significance to human health are well recognized and known to result from the use of antimicrobials in livestock. Consequently, antimicrobial use in food-producing animals is considered to present a risk to human health [11]. While this risk is presently unquantifiable in a precise manner, isolated incidents of such transfer are widely described in the literature [8,12-15]. Research into intensive agricultural systems have identified that the intestinal microbiota of food producing animal species can act a source of resistant bacteria for those working and living in close proximity [16-18], while multi-drug resistant bacterial zoonosis are frequently described and may represent a major threat to public health [19-21]. In light of these early indicators of risk, it has been considered prudent that restrictions are placed on the use of antimicrobials in both veterinary and human medicine, with the aim of slowing the emergence of resistance [12,22,23].

A call has been made to create an intergovernmental panel for AMR [24] and, more recently, the challenges of AMR have been expressed as a quintessential One Health issue [25]. These calls highlight the need for a multi-government, multi-sectoral, and multi-species approach. To support these aspirations, innovative ways for surveillance and monitoring of antimicrobial use and AMR are required to address major gaps in knowledge on the use of antimicrobials in livestock and aquatic farmed species. This innovation needs to be led by, or at least include, the private sector. A broader analysis is needed in which understanding antimicrobial use includes analyzing the institutional, social, and economic environments within which decisions are made [26].

AMR and the livestock and aquatic species should be viewed as an antimicrobial use/AMR complex due to its multi-dimensional nature with influence on: food production and productivity, pathogen management, AMR change, and environmental and human health impacts. Interpretation of AMR findings requires a more complete understanding of the inputs to the system, antimicrobial use, and antimicrobial residues in the environment and animal products. This challenge starts with basic 
building blocks with a focus on areas of likely highest risk. Surveillance, research, and interventions must all be designed to be applicable to the context of the specific situation in each country [27].

In South-East Asia, a large number of antimicrobials are used in the livestock sector, and studies suggest that AMR may be widely prevalent [28]. Weak or non-existent regulatory frameworks governing antimicrobial use, sub-optimal enforcement, and compliance with existing guidelines, low levels of AMR awareness, and inadequate commitment to responsible antimicrobial stewardship are driving the development of AMR. Regionally, AMR mitigation measures in the livestock sector lag behind the human health sector, and there remain gaps in data and information across the pharmaceutical and food sectors. These knowledge gaps limit the assessment of antimicrobial use and, therefore, create difficulties in determining levels and flows of residue and AMR across the food system. The current study developed a framework to characterize and describe the antimicrobial use/AMR complex in three key countries in South East Asia including Indonesia, Thailand, and Vietnam. The World Bank classifies Indonesia and Vietnam as lower-middle income countries while Thailand classifies as an upper-middle income country [29]. Some key statistics related to the economy and agricultural sectors in each country are shown in Table 1.

Table 1. Key statistics on the economic status and agricultural sectors in Indonesia, Thailand, and Vietnam in 2017.

\begin{tabular}{cccc}
\hline & Indonesia & Thailand & Vietnam \\
\hline Population (million) & 264 & 69 & 93.6 \\
GDP in (billions US\$) & 932 & 455 & 220.4 \\
GDP per capita (US\$) & 3530 & 6594 & 2355 \\
\% of the population residing in urban areas & $55 \%$ & $50 \%$ & $34 \%$ \\
\% of population employed in the agricultural sector & $31 \%$ & $49 \%$ & $35 \%$ \\
\hline & $2.3 \mathrm{~kg}$ (pork) & $10.4 \mathrm{~kg}$ (pork) & $30.4 \mathrm{~kg}$ (pork) \\
Average meat consumption per capita & $7 \mathrm{~kg}$ (poultry) & $14.5 \mathrm{~kg}$ (poultry) & $13 \mathrm{~kg}$ (poultry) \\
& $1.8 \mathrm{~kg}$ (beef and veal) & $1.7 \mathrm{~kg}$ (beef and veal) & $9.9 \mathrm{~kg}(\mathrm{beef} \mathrm{and} \mathrm{veal)}$ \\
& $0.4 \mathrm{~kg}$ (sheep) & $0.1 \mathrm{~kg}$ (sheep) & $27 \mathrm{~kg}$ \\
\hline Average fish consumption per capita & $47.1 \mathrm{~kg}$ & $33.7 \mathrm{~kg} *$ &
\end{tabular}

* 2016 data. Sources: https://data.worldbank.org/indicator.

The framework has three phases to explore the antimicrobial use/AMR complex in livestock systems. First, a detailed literature review identified existing knowledge and defined the major questions on the costs and benefits of antimicrobial use. Second, detailed case studies were undertaken to address some of these knowledge gaps described. In the final phase, a detailed analysis and discussion about the case study and literature review results was presented.

The application of the framework has allowed the development of informed policy suggestions and identified information gaps and priority areas for future research, which this paper summarizes. An exploration of the economic importance as of antimicrobials through the case studies has identified the challenges, and potential negative consequences, of policy to reduce use on small commercial livestock systems. As previously outlined, it is essential that AMR is addressed from a One Health perspective and such farmers' livelihoods need to be considered, in parallel with the human and animal health concerns from antimicrobial use in livestock. Thus, the framework highlights the importance of collecting accurate farm productivity data and undertaking economic assessments in any interventions to reduce antimicrobial use in LMICs.

\section{Results}

\subsection{An Overview of Livestock Production Systems}

\subsubsection{Pig Production}

Pork is an economical and sustainable protein source [30]. Pigs are typically reared in intensive systems with many features being uniform internationally such as indoor production, slatted systems, 
the use of commercially mixed feed, and sow crate systems [31]. Pig production is socially and economically important in Vietnam where three-quarters of meat consumed is pork. Pork is less important in Indonesia where, due to religious beliefs, it is only consumed by around $13 \%$ of the population [32,33]. An overview of the pig production sectors is presented in Table 2.

Table 2. An outline of the key characteristics of pig production in Indonesia, Thailand, and Vietnam.

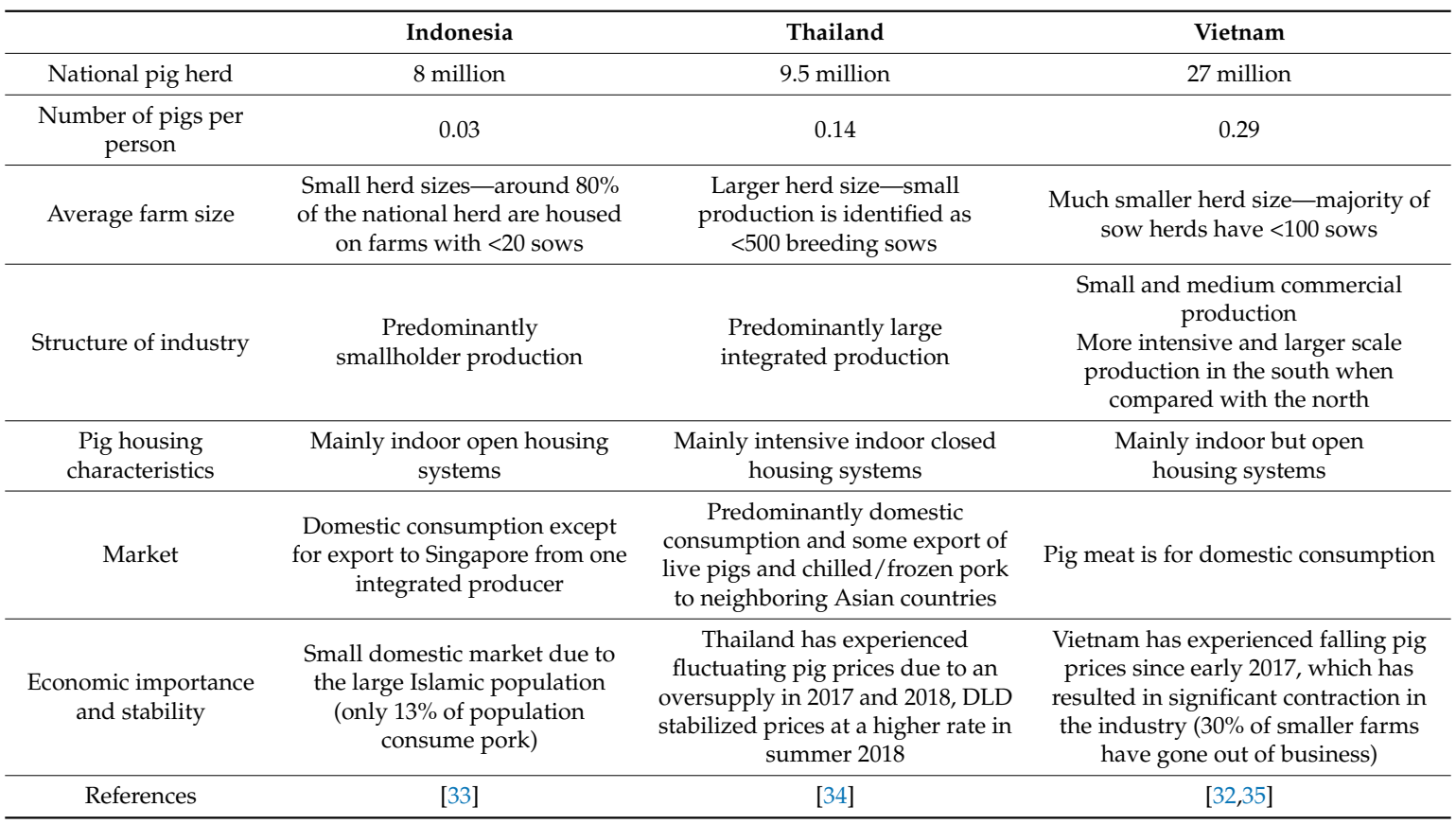

Detailed case studies in Vietnam and Thailand addressed the antimicrobial use/AMR complex in the pig sectors. There were many parallels between the production systems on the case study farms in these countries where the housing and management systems are similar but with marked differences in the scale of production. Overall, the farms observed in Thailand were on a much larger scale and were more likely to be part of an integrated supply chain than those in Vietnam. Additionally, pig production was of a greater economic significance to the individual households interviewed in Thailand when compared with Vietnam. An overview of the production systems from the case studies are shown in Table 3.

Table 3. Demographic information of the sample of pig farms for the case studies in Thailand and Vietnam.

\begin{tabular}{cccc}
\hline \multirow{2}{*}{ Number of Farms in Sample } & Thailand & Vietnam \\
\cline { 3 - 4 } & & $\mathbf{1 1}$ & $\mathbf{4 0}$ \\
\hline \multirow{3}{*}{ Median number of pigs } & Sows and boars & 635 & 5.5 \\
& Piglets (pre-weaning) & 1550 & 20 \\
& Feeding pigs (post-weaning) & 3100 & 40 \\
\hline \multirow{2}{*}{ Type of production system } & Farrow to finish farms & $85 \%$ & $55 \%$ \\
& Breeding only farms & $5 \%$ & $18 \%$ \\
& Fattening only farms & $10 \%$ & $27 \%$ \\
\hline \multicolumn{2}{c}{ Median percentage of annual income from pigs } & $50 \%$ & $75 \%$ \\
\hline
\end{tabular}

\subsubsection{Broiler Production}

Globally, broiler production is undergoing a process of intensification with the increasing dominance of integrated supply chains [36]. Broiler meat is of a high economic importance across all 
the case study countries with the greatest importance found in Thailand and Indonesia. Indonesia has a large domestic market for broiler meat, which is estimated to be $87 \%$ of all meat consumed [37]. Thailand, in addition to national markets, has a large export market, which is of great economic significance within the region [38]. An overview of the broiler production sectors is shown in Table 4.

Table 4. An outline of the key characteristics of broiler production in Indonesia, Thailand, and Vietnam.

\begin{tabular}{|c|c|c|c|}
\hline & Indonesia & Thailand & Vietnam \\
\hline National broiler flock & 3.5 billion & 1.1 billion & 323 million \\
\hline $\begin{array}{l}\text { Number of broilers } \\
\text { per person }\end{array}$ & 13.26 & 15.94 & 3.45 \\
\hline Average farm size & $\begin{array}{l}\text { Smaller flock sizes with } \\
\text { most being 5000-20,000 }\end{array}$ & $\begin{array}{l}\text { Large scale production with an } \\
\text { average of } 70,000 \text { birds in a flock }\end{array}$ & $\begin{array}{l}\text { Average flock sizes } \\
<2000 \text { birds }\end{array}$ \\
\hline Structure of industry & $\begin{array}{l}\text { Commercial integrated } \\
\text { production companies } \\
\text { producing broilers on } \\
\text { small contract farms }\end{array}$ & $\begin{array}{l}\text { Commercial integrated } \\
\text { production on large farms } \\
\text { Mixture of company farms and } \\
\text { some on contract farms }\end{array}$ & $\begin{array}{l}\text { Smallholder and small } \\
\text { commercial systems }\end{array}$ \\
\hline $\begin{array}{l}\text { Broiler housing } \\
\text { characteristics }\end{array}$ & $\begin{array}{l}\text { Mainly open } \\
\text { housing systems }\end{array}$ & $\begin{array}{l}\text { Mainly closed and automatically } \\
\text { ventilated housing }\end{array}$ & $\begin{array}{c}\text { Mainly open } \\
\text { housing systems }\end{array}$ \\
\hline Market & $\begin{array}{l}\text { Broiler meat is for } \\
\text { domestic consumption }\end{array}$ & $\begin{array}{l}\text { Thailand has an important export } \\
\text { market for broiler meat }\end{array}$ & $\begin{array}{l}\text { Limited export market } \\
\text { from larger integrated } \\
\text { production }\end{array}$ \\
\hline $\begin{array}{l}\text { Economic importance } \\
\text { and stability }\end{array}$ & $\begin{array}{l}\text { Economic growth in } \\
\text { the industry }\end{array}$ & $\begin{array}{l}\text { Economic growth in broiler } \\
\text { production in Thailand after } \\
\text { recovery from Highly Pathogenic } \\
\text { Avian Influenza (HPAI) outbreak }\end{array}$ & $\begin{array}{l}\text { Some economic } \\
\text { instability historically to } \\
\text { the effects of HPAI. } \\
\text { However, there is now } \\
\text { growth in the sector. }\end{array}$ \\
\hline References & [39-41] & {$[38,42]$} & {$[43,44]$} \\
\hline
\end{tabular}

There is an ongoing transition across Asia from traditional open housing systems to modern closed and automated systems. This transition has been somewhat accelerated due to the outbreaks of Highly Pathogenic Avian Influenza (HPAI) in the early 2000s [36,45]. The type of housing system is where the main contrasts are observed between broiler production in Thailand, Indonesia, and Vietnam. Thailand has undergone a more rapid transition toward intensive production with a modern, integrated, and intensive broiler industry producing birds for export. The majority of production is from closed systems with automated and controlled environments [38]. In contrast, the transition has been slower in Indonesia and Vietnam with the majority of farms still being smaller scale, open housing with low biosecurity, high mortality rates, and disease signs.

\subsubsection{Aquaculture Production}

Aquaculture production systems are of growing importance, as global demand for fish continues to rise [46]. This increased demand has been met by a move toward more intensive aquaculture systems with this transition being most advanced in the shrimp sector. The Asian continent is of great significance to international shrimp supply and accounts for $85 \%$ of global aquaculture production. However, the emergence of Early Mortality Syndrome (EMS) in 2011 has resulted in a fall of 13\% in international shrimp production with Vietnam and Thailand suffering heavy losses [47]. An overview of the aquaculture production sector is shown in Table 5. 
Table 5. An outline of the key characteristics of aquaculture production in Indonesia, Thailand, and Vietnam.

\begin{tabular}{|c|c|c|c|}
\hline & Indonesia & Thailand & Vietnam \\
\hline $\begin{array}{l}\text { Total Production in } \\
\text { Metric Tons of } \\
\text { Live Weight }\end{array}$ & 547,934 in 2012 & 376,339 in 2013 & 806,960 in 2013 \\
\hline $\begin{array}{l}\text { Export Volume in Metric } \\
\text { Tons of Live Weight }\end{array}$ & $\sim 270,000$ in 2012 & $\sim 330,000$ in 2013 & 600,000 in 2013 \\
\hline $\begin{array}{l}\text { Dominant aquaculture } \\
\text { sectors }\end{array}$ & $\begin{array}{l}\text { Brackish water-Shrimp } \\
\text { and milkfish. } \\
\text { Freshwater-Tilapia, catfish, carp, } \\
\text { and grouper. }\end{array}$ & $\begin{array}{l}\text { Brackish water-Whiteleg } \\
\text { shrimp, green mussel, blood } \\
\text { cockle, and oyster. } \\
\text { Freshwater-Nile tilapia } \\
\text { and catfish. }\end{array}$ & $\begin{array}{c}\text { Brackish water-Whiteleg shrimp } \\
\text { and tiger shrimp } \\
\text { Freshwater-Pangasuis catfish }\end{array}$ \\
\hline Structure of the industry & $\begin{array}{l}80 \% \text { of the industry is small-scale } \\
\text { extensive and semi-intensive cage, } \\
\text { net, and pond systems. } \\
\text { In addition, there is an emerging } \\
\text { intensive cage and net } \\
\text { systems sector. }\end{array}$ & $\begin{array}{c}\text { Improved extensive, } \\
\text { semi-intensive, and intensive } \\
\text { net and cage systems. } \\
\text { Intensive systems are } \\
\text { dominant for shrimp } \\
\text { production for export. }\end{array}$ & $\begin{array}{l}\text { Improved extensive, } \\
\text { semi-intensive, and intensive net } \\
\text { and cage systems }\end{array}$ \\
\hline Market & $\begin{array}{l}38 \% \text { of aquatic production is } \\
\text { produced for export and there is a } \\
\text { large and rapidly growing export } \\
\text { market. }\end{array}$ & $\begin{array}{l}88 \% \text { of aquaculture products } \\
\text { are for the export market. }\end{array}$ & $\begin{array}{l}\text { Shrimp farming accounted for } \\
94 \% \text { of Vietnam's export market is } \\
\text { 2014. Pangasuis catfish contribute } \\
\text { toward both the domestic and } \\
\text { export market. }\end{array}$ \\
\hline $\begin{array}{l}\text { Economic importance } \\
\text { and stability }\end{array}$ & $\begin{array}{l}\text { Indonesia has made large-scale } \\
\text { investments in intensive white leg } \\
\text { shrimp farming and exports over } \\
\text { half of shrimp produced. } \\
\text { The export value }>\$ 1 \text { billion. }\end{array}$ & $\begin{array}{l}\text { EMS had a devastating effect } \\
\text { on the shrimp sector in } \\
\text { Thailand from } 2011 \text { through } \\
2014 \text { with high mortality rates. } \\
\text { Economic recovery is ongoing. }\end{array}$ & $\begin{array}{l}\text { Aquaculture is very important to } \\
\text { Vietnam's economy and } \\
\text { contributed } 10 \% \text { toward the } \\
\text { country's GDP. However, Vietnam } \\
\text { has suffered significant losses due } \\
\text { to EMS. }\end{array}$ \\
\hline
\end{tabular}

\subsection{Antimicrobial Use Policy and Surveillance}

As in many other LMICs, there is currently no requirement for a prescription for the use of antimicrobials in animals or humans in any of the case study countries [52]. However, Thailand has led the way in applying stricter regulations on antimicrobial use in livestock with measures including a ban since 2015 on the use of antimicrobials for growth promotion. In 2017, the antimicrobial classes identified by the World Health Organization (WHO) were identified as being the highest priority, critically important antimicrobials (HP-CIAs) for human medicine, which are only available in veterinary prescription (polymixins, third and fourth generation cephalosporins and fluoroquinolones) [53-55]. In comparison, Vietnam and Indonesia currently have fewer restrictions on the use of antimicrobials in animals, but both countries prohibited the use of antimicrobials for growth promotion at the beginning of 2018. If the development of antimicrobial use policy is considered to be a stepwise process, with a prescription-only status for antimicrobials for use in animals being the final goal. Then Indonesia and Vietnam started the process two years after Thailand. For example, the introduction of a national strategy for AMR was launched in Thailand in 2015 while the equivalent strategies were not initiated in Indonesia and Vietnam until 2017 [54,56,57].

Stricter legislation on antimicrobial use may be seen as a positive step in the global fight against AMR, which, to be truly effective, requires the development of enforcement capacity. For example, despite a more extensive infrastructure and tighter control over antimicrobial use in Thailand, researchers have described black market and illegal use of antimicrobials in livestock [58,59], while antimicrobial residues have been identified in eggs and meat from retail outlets in Vietnam despite regulation of maximum residue limits [60,61]. In addition, the case studies identified that farmers were reluctant to adopt new legislation. The majority $(>75 \%)$ of farmers believed that there was an economic advantage to antimicrobial use in livestock and reported that antimicrobials contributed toward greater farm profitability and lower mortality rates in livestock. In addition, $27 \%$ of Indonesian broiler producers in the case study stated that an improvement in the growth rates of birds motivated 
their use of antimicrobials. Data around the growth and production response to antimicrobials are poorly documented in the types of systems studied and the assumption that there will be no impact on productivity with a change in use needs more careful research.

In Indonesia and Vietnam, antimicrobial use surveillance in animals are either absent or restricted to small surveys or national estimates such as the data presented in the OIE report on global antimicrobial use [62]. The accuracy of national estimates on antimicrobial consumption is often questionable due to the large number of assumptions made to collate these data. In comparison, Thailand has some data available on national antimicrobial consumption in livestock. The Animal Health and Products Association (AHPA), which is the trade association for veterinary pharmaceuticals, has collated antimicrobial sales data to estimate antimicrobial use. Since 2013, the AHPA has used the European Surveillance for Veterinary antimicrobial Consumption (ESVAC) metric of mg of antimicrobial per population correction unit (mg/PCU). These data identified pigs to be the species with the highest consumption of antimicrobials with a value of $238 \mathrm{mg} / \mathrm{PCU}$ in fattening pigs compared to $16 \mathrm{mg} / \mathrm{PCU}$ in broiler chickens [63].

Indonesia has an established animal health surveillance system as the 'integrated animal health information system,' which is referred to as iSIKHNAS. This is a farmer-based reporting system for disease, animal population, and animal treatments [64]. The system also requires that all government veterinarians and para-veterinarians report any medicine usage [65]. This program has proved to be an effective method for capturing antimicrobial use data for small beef production. However, it rarely captures data on commercial broiler or pig farms $[64,65]$.

\subsection{Antimicrobial Use Behaviors}

\subsubsection{Pig Production}

The focus of the case studies in Thailand and Vietnam was the small-medium commercial pig sector. The literature review highlighted this sector as having relatively high antimicrobial use in comparison to backyard or large integrated production systems $[20,32,66]$. In addition, this sector may present a larger human population employed along the supply chain, and, thus, is at risk of exposure to antimicrobials with more labor-intensive systems and manual slaughterhouse facilities. These farms are also more likely to supply local wet markets, which may present a greater food safety risk when compared with the more formal retail supply chain [67].

In Asian LMICs, antimicrobials are freely available over the counter for use in both humans and animals [58,68]. Therefore, many farmers administer antimicrobials without the guidance of a veterinarian and source products directly from pharmaceutical companies, drug sellers, or pharmacies. However, the survey found that the majority of the respondents in Thailand and Vietnam identified the veterinarians to be the most important people in monitoring the prudent use of antimicrobials in pigs. In parallel, there was a shared opinion that the government was important in monitoring the responsible use of antimicrobials in pigs. Conversely, many farmers did not consider themselves accountable for monitoring the prudent use of antimicrobials in pigs. Farmer attitudes for monitoring the prudent use of antimicrobial nature in pigs are shown in Figure 1.

All of the pig producers in the case studies in Thailand and Vietnam identified that there was an economic advantage to the use of antimicrobials in pigs. The most frequently volunteered justifications were that antimicrobials improved farm profitability, reduced mortality, and improved pig productivity (Table 6). Influences of antimicrobial use in Thailand included the presence of disease, increasing mortality rates, and drug seller advice. No farmers reported that antimicrobials were used to improve farm productivity, but they reported that antimicrobial use for growth promotion was a justified practice $(82 \%, n=11$ in Figure 2$)$. 


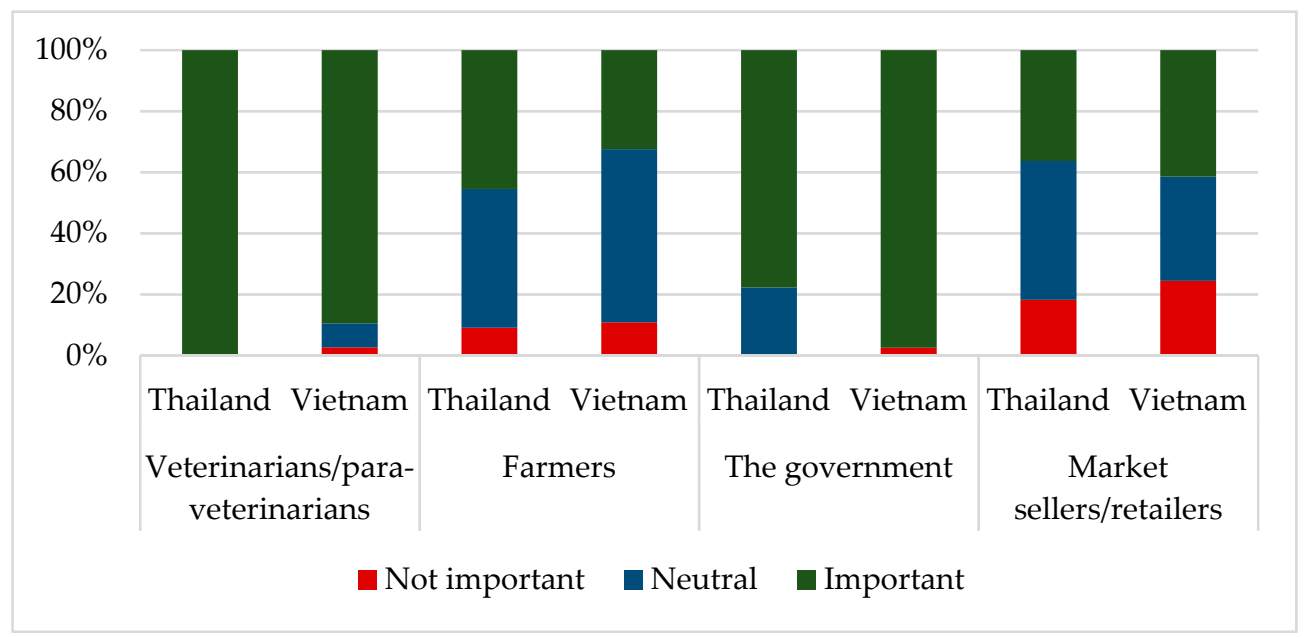

Figure 1. Farmer attitudes to the roles of different actors in monitoring the prudent use of antimicrobials in pigs.

Table 6. Farmer volunteered responses to the economic advantages of the use of antimicrobials in pig farms in a case study regarding pig production in Thailand and Vietnam.

\begin{tabular}{ccccc}
\hline & \multicolumn{2}{c}{ Thailand } & \multicolumn{2}{c}{ Vietnam } \\
\hline Volunteered responses & No. & Percentage & No. & Percentage \\
Improves farm profitability & 7 & $41.2 \%$ & 24 & $32.0 \%$ \\
Reduces mortality & 5 & $29.4 \%$ & 21 & $28.0 \%$ \\
Increases pig herd productivity & 2 & $11.8 \%$ & 15 & $20.0 \%$ \\
Antimicrobials are not expensive & 1 & $5.9 \%$ & 12 & $16.0 \%$ \\
Reduces culling rates & 1 & $5.9 \%$ & 0 & $0.0 \%$ \\
Reduces morbidity & 1 & $5.9 \%$ & 3 & $4.0 \%$ \\
\hline
\end{tabular}

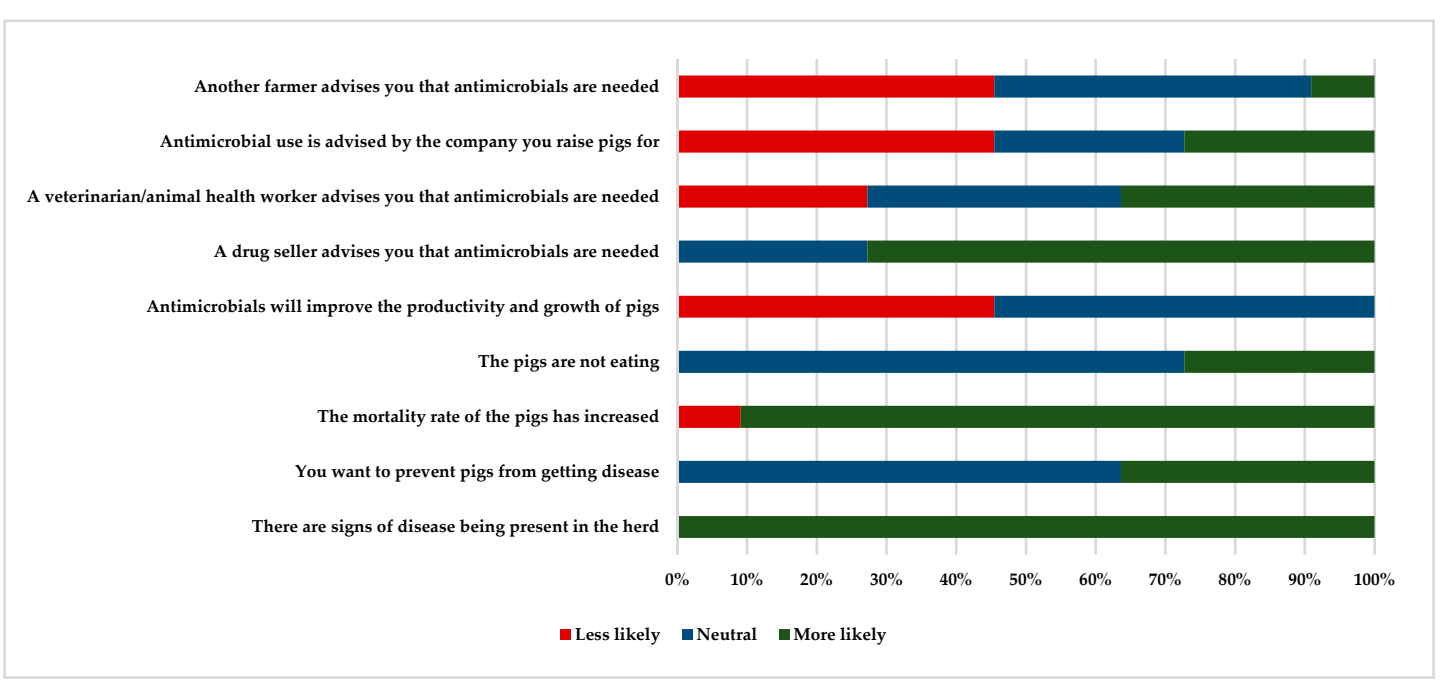

Figure 2. The behavioural influences behind antimicrobial use in a case study on antimicrobial use on pig farms in Thailand $(n=11)$.

The case studies also sought to collect quantitative data on antimicrobial use by indication, formulation, and active ingredient (Table 7). The penicillin, tetracycline, and aminoglycoside classes were the most commonly reported antimicrobial usages across pig production systems in both countries. However, there were some contrasts in antimicrobial use behaviors observed. For example, the phenicol class accounted for around a third of reported antimicrobial usages in Vietnam when compared with 
minor use $(1.7 \%)$ in Thailand. Antimicrobial use of the HP-CIA classes was more frequent in Thailand (32\%) when compared to Vietnam (21\%) (Figure 3).

Table 7. Characteristics of antimicrobials used in a case study in antimicrobial use in pig production in Thailand and Vietnam.

\begin{tabular}{cccc}
\hline \% of Antimicrobial Products Reported to Be Used Routinely on Farms & Thailand & Vietnam \\
\hline \multirow{2}{*}{ Route of administration } & Parenteral & $56 \%$ & $80 \%$ \\
& In-feed & $40 \%$ & $19 \%$ \\
\hline \multirow{2}{*}{ Indication for use } & Treatment & $60 \%$ & $84 \%$ \\
& Prevention & $29 \%$ & $10 \%$ \\
\hline \multicolumn{2}{c}{ Combination of two or more antimicrobials } & $11 \%$ & $7 \%$ \\
\hline
\end{tabular}

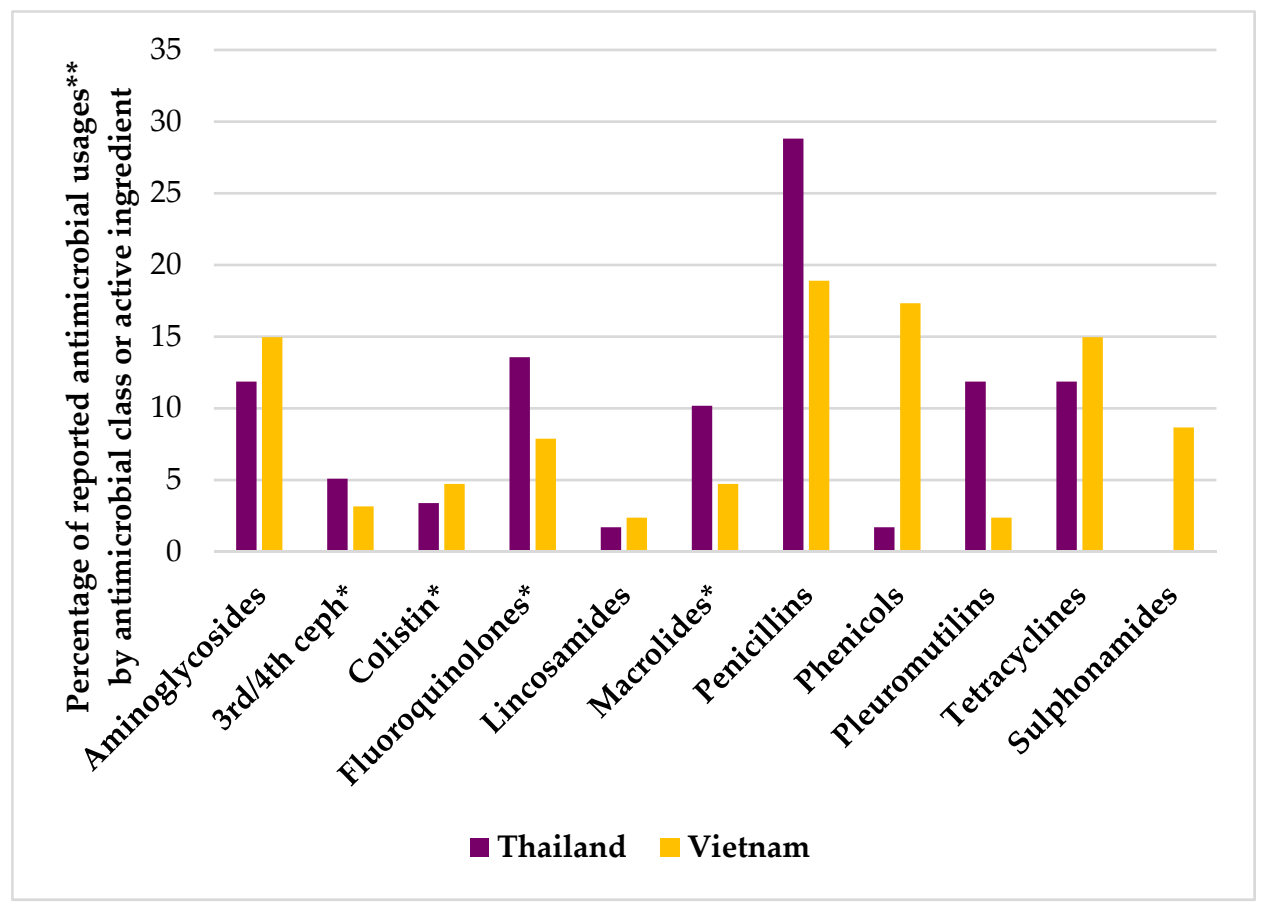

Figure 3. Reported antimicrobial usages by active ingredient (\%) in a case study into antimicrobial use in pig production in Thailand and Vietnam. *Antimicrobial class classified by the WHO as the highest priority as critically important antimicrobial (HP-CIA). ${ }^{* *} \mathrm{~A}$ 'reported antimicrobial usage' was considered the use of an antimicrobial active ingredient or the use of the same active ingredient in a different formulation, as reported by the farmer. In the case of a combination of antimicrobial product, each active ingredient was counted as differently reported antimicrobial usage.

The collection of these antimicrobial use data presented some challenges. First, some of the commercially mixed feed on farms did not include information on the ingredients or antimicrobial content on the feed labels. Therefore, in-feed antimicrobial use may be under reported. Second, the bin collection method used in the Vietnamese case study proved to be an inefficient method of collecting quantitative antimicrobial use data. There was poor understanding of the methodology by many participants and, consequently, few farms retained antimicrobial packaging for the full six-week study period.

\subsubsection{Broiler Production}

The focus of the case study in Indonesia was the small-medium commercial broiler sector. The literature review identified that the Indonesian broiler sector relies heavily on antimicrobials 
for routine disease prevention programs [65]. In addition, while the industry has undergone rapid intensification, the majority of Indonesian farms are still open housing systems. These systems pose a significant disease risk and are considered to have low levels of farm biosecurity [39], but are probably more aligned to the economic reality of producing chicken in Indonesia.

The influences behind antimicrobial use behaviors in the small-medium broiler sector in Indonesia identified that the active presence of disease, increasing mortality rates, and an aspiration to prevent disease were major drivers of antimicrobial use on the case study farms. In addition, in spite of a ban on the use of antimicrobials for growth promotion, $27 \%(n=419)$ of respondents identified that an improvement in productivity and growth was a motivation toward antimicrobial use. The majority of farmers $(44 \%)$ considered that advice from veterinarians or para-veterinarians would drive antimicrobial use and $88 \%$ identified that veterinarians played an important role in monitoring the prudent use of antimicrobials. Equally, the dominant opinion was that the government (85\%) and farmers (80\%) played an important role in monitoring antimicrobial use in broilers in Indonesia. The behavioral influences behind antimicrobial use are shown in Figure 4.

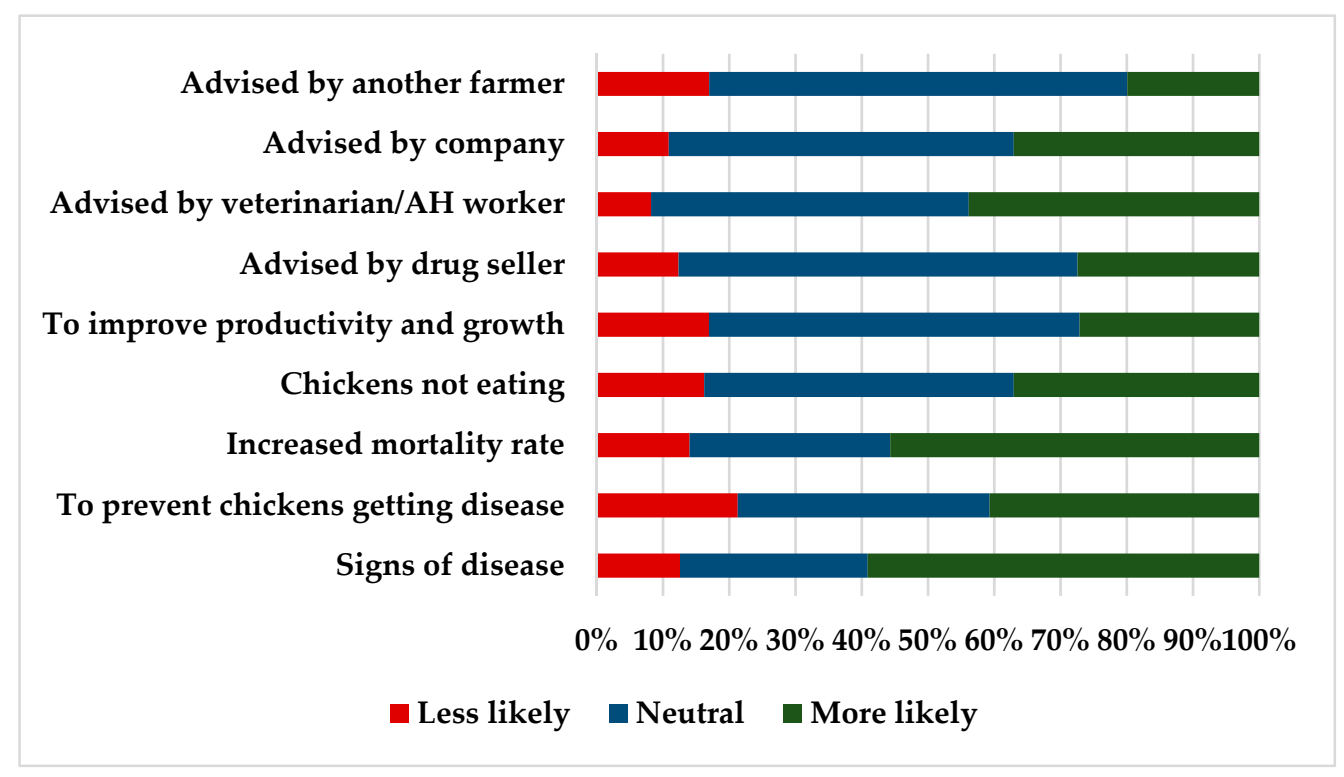

Figure 4. The behavioral influences behind antimicrobial use in a case study on antimicrobial use on broiler farms in Indonesia $(n=419)$.

Overall, $81 \%$ of farmers identified that there was an economic advantage in using antimicrobials in broilers with increased productivity and healthier chickens being the most commonly cited reasons (Table 8). In parallel, the majority of farmers (88\%) felt that disease had a negative effect on farm profit margins. However, $21 \%$ did not record any production data. When production data were collected, mortality rates $(23 \%)$, body weight $(22 \%)$, and sale price $(12 \%)$ were most frequently recorded.

The case study sought to describe baseline knowledge of farmers on the issue of AMR. In an open response question, only $45 \%(n=419)$ of broiler farmers were able to correctly define AMR. The most frequent definition was that AMR is 'resistance to drugs.' However, some offered a more general description that AMR 'caused treatment to be ineffective'. However, $56 \%$ of farmers identified that AMR was a major challenge in human medicine and an equal number felt that antimicrobial use in broilers might affect the health of consumers. 
Table 8. Justifications for the economic advantage for antimicrobial use by farmers in a case study into antimicrobial use in broilers in Indonesia.

\begin{tabular}{cccc}
\hline & No. & Percentage & Quotations \\
\hline Increased productivity & 108 & $33 \%$ & $\begin{array}{c}\text { 'Accelerate chicken growth.' } \\
\text { 'Very good for chicken body weight.' } \\
\text { 'Stable body weight with rising tendencies.' } \\
\text { 'Reduce mortality.' }\end{array}$ \\
Realthier chickens & 97 & $29 \%$ & 'Mortality rates can be reduced.' \\
For disease prevention & 66 & $25 \%$ & 'Chickens will be healthy if medicated with the right antibiotics.' \\
Treating disease & 37 & $11 \%$ & 'Prevent disease.' \\
\hline
\end{tabular}

\subsubsection{Aquaculture Systems}

Studies show that antimicrobial use is widespread in aquaculture systems in Indonesia, Thailand, and Vietnam [65,69-71]. Tetracyclines, fluoroquinolones, sulphonamides, and penicillins are important antimicrobial classes used in the sector $[65,69,71]$ and are most frequently sourced over the counter from feed supply shops. Since there are limited medicated feeds available, farmers manually mix antimicrobials into feed with a potential risk of inaccurate dosing and concerns over the public health consequences from exposure to active ingredients [65,69].

There are significant concerns over the presence of antimicrobial residues in fish and the potential for the transmission of antimicrobial resistant bacteria to humans through both food and the environment [72-74]. Multi-drug resistance has been identified in Escherichia Coli and Vibrio from environmental samples and shrimp for sale through retail outlets in Thailand $[73,75]$, while Pangasius catfish production is considered to represent a significant ecological risk from antimicrobial residues and resistant bacteria in the environment [76,77]. Integrated livestock-fish production systems, whereby manure is used as a feed for fish, are an economically important sector through Asia. However, these systems are under scrutiny for the potential risks to human health from antimicrobial residues [78]. For example, antimicrobial contamination of the environment and fish has been found to occur as a consequence of chlortetracycline administration to chickens in integrated chicken-fish production systems [79].

The discovery of antimicrobial residues in exported farmed shrimp has resulted in Japan imposing importation restrictions on Indonesia and Thailand [74]. Consequently, Thailand has introduced policy banning the use of medicated feeds in aquaculture, while Indonesia only permits the tetracycline, macrolide, and fluoroquinolone classes to be used in aquaculture systems [52,65]. Additionally, Vietnam has policy to restrict the use of enrofloxcin in aquaculture. However, a study by Thi Kim Chi et al. (2017) identified the sale of enrofloxacin in feed shops in two different provinces in Vietnam, which cast doubt over the enforcement of such legislation. Thus, while further exploration of aquaculture systems was beyond the scope of this framework, the sector presents a number of concerns with regards to antimicrobial resistance, residues, and policy enforcement. This is an area that warrants further research.

\subsection{The Economic Drivers for Antimicrobial Use}

An important step in defining the role of antimicrobials in pig and broiler production systems is to understand the costs and benefits to individual farmers. Ultimately, the role of the economic analysis is to be able to compare production under different input scenarios and identify the misallocation of resources through a search for optimal resource use under a set of prices for inputs and outputs. This search for optimal use has to compare production with and without antimicrobials and to compare the effect of using alternative non-antimicrobial interventions on production. The following presents an economic analysis of the Vietnamese and Thai pig production systems as well as the Indonesian broiler sector, but the scope of the study did not allow economic assessments of alternative levels of antimicrobials use and alternative interventions to antimicrobials in these systems. This requires 
longitudinal work as described by Carrique Mas and Rushton (2017) in order to refine the generic recommendation of 'reduction in antimicrobial use' toward a set of guidelines on how to reduce antimicrobial use with minimal impact on livestock production, profitability, and livelihoods and maximum impact on AMR management and general pathogen control [80].

The ability to undertake more detailed economic analyses was limited by the lack of detailed on-farm production and cost data. In these small-to-medium scale enterprises, farmers do not routinely collect any such data, which reflects the relative costs of data collection and the benefits gained from such activities in small production units. The project was able to provide initial estimates of the importance of antimicrobial costs to the economic viability of these small-to-medium scale production systems.

\subsubsection{Vietnam}

The economic analysis in Vietnam used the data from those farms who had sows in 36 rather than the 40 farms in the entire survey. The management and economic landscape of farms that specialized in fattening (three of the 40) was very different to those who managed a farrowing to fattening production system. In addition, a recent decline in price led to some of these fattening farms not purchasing weaners for fattening in the previous 12 months. One farm produced 900 fatteners and was regarded as an outlier in this study.

The gross margin analysis, difference between output and variable costs, indicates that returns have been poor during the time of this survey with two out of the three scenarios indicating losses to the farmer. The result supports the perceptions of the study team and enumerators that the pig sector was facing a difficult economic environment during this time.

Medicines and antimicrobials were only $2 \%$ of costs in the pig production system, which is an important result when considering policies on pricing as a way to manage antimicrobial use. As expected, feed was the most significant cost and, therefore, the input of greatest concern by farmers. The low cost of antimicrobials could well mean that farmers are not in a conscious process of searching for optimal antimicrobial use around a classic production function of output. Rather the use, as shown in the behavioral aspects, is in response to a mix of managing impacts of disease and health issues that support production. It is, likely, best described as a risk management strategy in an uncertain environment. While the internal farm costs are relatively low with current pricing, the potential externalities of poor on farm antimicrobial use leading to AMR risks to humans is not properly accounted for in the price. Further work is required to estimate the product development costs, the effects of AMR on future pig production and disease control, or the present and future effects on human health.

\subsubsection{Thailand}

With regard to the survey of pig farmers in Thailand, nine out of the 11 farmers surveyed had large herds. The data showed that they were selling an average of 334 pigs, probably fatteners, which would provide a weekly gross income of \$60,000 USD. Investing in medicines and, more specifically, antimicrobials turned out to be a very minor cost. Investing \$2.03 USD to maintain an asset of $\$ 180$ USD, most farmers regarded the value of a fattener as good value for money even if the actual benefits are unclear. Likewise, a preventive medication of $\$ 2.07$ to have potential health benefits to their breeding sows may seem to be a good investment.

Farmers were also requested to list the antimicrobials used, the active ingredients, cost per pack, and which pig age group they were used on. Once again, these data were very difficult to recall and some farmers could not, or would not, provide estimates. While routine antimicrobials could be estimated, it was not possible to estimate what antimicrobials were actually given as disease treatments. The antimicrobials were listed but farmers found it difficult to allocate costs to pigs in a cycle or year, so another measure was developed to show the relative importance of antimicrobials to the farming system. The conclusion is that, once again, antimicrobials are a very small cost to the farmer. For every 
kilogram of pig on the farm at the time of the survey, the farmers on average expect to spend, or at least identified costs of, $\$ 0.06 / \mathrm{kg}$ live weight on antimicrobials.

\subsubsection{Indonesia}

Gross margin data and antimicrobial costs per cycle were not able to be estimated from the survey data. The economic analysis, therefore, considered some alternative measures. First, a more simplified analysis that assesses whether or not there are differences in medicine costs between farmers' performance index (Performance Index $=(($ weight at sale $[\mathrm{gms}] /$ age at sale [days] $) \times$ liveability $[\%]) / F C R \times 10$ ) results in their last broiler cycle. The study identified the possibility that the higher the performance index is, the lower the use of medicines are. The farmers with the highest performance index (highest $25 \%$ of farmers) invest, on average, Indonesian Rupiah350/bird (US\$0.02/bird) on medicines. The range for the other farmers is between IDR390 and IDR405/bird. While this may be a small difference in costs per bird when extrapolated over the whole flock, it may be significant.

The survey collected information concerning the number of days that antimicrobials were used on the most recent batch of broilers. This may be used as a proxy for antimicrobial usage on the farm. It may be that, the more days that antimicrobials are used, the more antimicrobials are actually used. Although this does not provide insights into the reasons for use or even the types of antimicrobials used, it still may provide useful information concerning the extent of use. The analysis showed that, with regard to farm size, there is a slight difference between smaller farms and the larger farms with respect to the number of days that antimicrobials are used. The larger farms may tend to use less antimicrobials than the smaller farms.

Another useful measure is the correlation between the average performance index and the number of days that antimicrobials are used. There may be a positive relationship between antimicrobials and the index. The more days that antimicrobials are used, the higher the performance index is. The context of these results is that antimicrobial use in this system tends to be a preventative measure with advice from the contract company to use antimicrobials if bad (hot or cold) weather is expected and fear of respiratory disease. In addition, farmers, particularly independent producers, often give antimicrobials on the day the one-day old chick arrives since this is a critical point in the production process. There are often doubts about the strength of the newly arrived bird to survive the transition from the hatchery to the farm.

\section{Discussion}

\subsection{Drivers for Antimicrobial Use in Livestock}

The small commercial livestock sector runs on tight profit margins and producers are highly susceptible to changes in market prices. This economic vulnerability has been shown through the Vietnamese pig industry since the sector has experienced a turbulent economic scene since early 2017 with falling pig prices from an oversupply of pork and a cessation of exports to China. As a consequence, it has been estimated that around 30\% of smaller pig farms have gone out as a business in Vietnam [81,82]. With farms balanced precariously between profitability and loss, it is essential that the economic landscape of antimicrobial use is mapped to ensure a future sustainable food supply.

Keeping detailed farm records on livestock production can enable farmers to identify which areas of their business may benefit from additional investment and where losses may be occurring. These data are also required to present to financial lenders for proof of reinvestment potentials on the farm [83]. However, either many of the farmers in the case study did not keep records or production data records were limited. There is scope for further engagement of farmers to review how data are collected and how benefits can be generated in terms of improved management and biosecurity to improve farm profitability, manage risk, and reduce variation.

Farm profitability, disease prevention, and reducing mortality rates were identified as drivers towards antimicrobial use in livestock systems. In broiler systems in Indonesia, the use of antimicrobials 
in feed were identified as a method of compensating for the significant disease burden seen in open housing systems [84]. While the Indonesian broiler sector is undergoing a process of intensification, with a move towards closed automated housing systems, this shift is predominantly in the large integrated sector [39]. Therefore, at present, the small-scale broiler sector presents a number of challenges concerning disease prevention and there is concern that any regulation to restrict access to antimicrobials may result in some farms being unable to economically produce broilers.

The use of medicated feed to prevent disease is a frequent practice in global livestock systems [85]. This behavior was identified in all of the case study countries, but it was potentially under-reported in the pig sector. For example, through the Vietnamese case study, some of the commercial mixed feed was found to be missing feed ingredient listings while evidence from the literature suggests that over half of commercial pig feed contains antimicrobials [86]. Issues with misleading and imprecise labelling of livestock feed has been identified in other studies in the region and improving the regulation of feed labelling is a priority area for AMR policy in South East Asia [52,86,87].

The use of antimicrobials for disease prevention is a contentious issue and there is increasing pressure to discontinue this practice internationally $[5,8,88]$. There has been a move in many high income countries (HICs) for chicken broiler production that do not use antimicrobials. This has has been driven, in part, by food companies seeking a market for livestock products from antimicrobial free systems, but there are welfare implications for these systems. For example, chicken broiler systems that do not allow drug use for the control of coccidiosis in addition to prohibiting antibiotic use can suffer disease consequences [89]. It was reported that broiler production in Thailand by one of the major integrator companies was producing broiler meat for export under antimicrobial-free conditions [90].

The easy availability of antimicrobials over the counter and from a range of sources results in antimicrobial costs remaining consistently low throughout Asia [68]. The study identified that, in pig and poultry systems, the cost of antimicrobials was low relative to other inputs. The antimicrobial use was driven by response to advice from others and by the presence and risk of disease or an animal health issue. A policy to increase antimicrobial prices may generate a rapid decline in use. However, there are concerns that increasing costs may incentivize farmers to source antimicrobials from the black market. In Thailand, an increasing price of feed containing premixed antimicrobials has resulted in some farmers purchasing antimicrobial active ingredients to mix into feed manually in spite of regulations prohibiting such behaviors. This practice may pose a risk to human health from farmer exposure to active ingredients in the mixing process [58]. Therefore, it is essential that the potential for such behaviors be considered in any future regulation of in-feed antimicrobial use to mitigate these risks to farmers. The previously mentioned example shows that regulation alone cannot be considered sufficient to control antimicrobial use behaviors. There also needs to be sufficient resources to enforce policy.

A ban on antimicrobial growth promoters in Denmark was shown to increase the need for antimicrobials for therapeutic indications in the years following the ban [91]. This was believed to be linked with increasing levels of disease previously masked by the use of growth promoters and the associated reductions in productivity. Antimicrobial growth promoters are considered to be particularly beneficial for disguising subclinical disease on unhygienic and older livestock housing systems [92]. Therefore, it seems likely that the antimicrobial growth promoter ban will have an effect on the overall productivity of the livestock sectors, which are concerns echoed by participants in the case studies. It is essential that producers receive sufficient support to seek alternative management routes for preventing disease.

There is a grey area around prophylactic and growth promoting antimicrobial use whereby studies have shown that producers may use antimicrobials for growth promotional effects, but justify this practice as being for disease prophylaxis [93,94]. Dang et al. (2013) identified that high and inappropriate doses of antimicrobials were frequently used in pigs in the Red River Delta region and that course lengths were frequently sporadic. Such irresponsible behaviors may suggest that inappropriate use for disease prevention or potentially growth promotion may still be an issue 
globally. The case study results support this theory by showing poor farmer awareness of the ban on antimicrobial growth promoters and many considered livestock growth to be a driver for antimicrobial use. Thus, there is a need for further knowledge exchange with producers, veterinarians, and key livestock stakeholders concerning the legislation prohibiting the use of antimicrobial growth promoters. This is likely to pose a significant challenge for the enforcement of national bans and is an area of concern throughout South East Asia, which requires enhanced financial support and resources to properly enforce the legislation [52].

The case study results identified the frequent use of the HP-CIA classes in all livestock groups. There has been increasing international pressure to reduce or discontinue the use of HP-CIA classes in livestock [6,8]. Efforts to address this has varied from voluntary or legislative bans in some European countries [95-97] to a requirement for a veterinary prescription for their use in Thailand [54]. The implementation of national action plans on AMR aim to advocate optimal antimicrobial use practices. However, this framework has highlighted that reductions in antimicrobial use are likely to result in significant economic losses and high mortality rates. Therefore, it would be worthwhile to prioritize policies based on risks to human and animal health. One potential route would be to focus initial restrictions on antimicrobial classes considered to be of greater importance to human medicine.

Restricting access to antimicrobials by removing over-the-counter sales has been identified as a potential route to better antimicrobial use in animals in such countries $[7,8]$. However, there are ongoing concerns that restricting access to prescription-only may result in some communities becoming unable to access antimicrobials [98]. Conversely, evidence from human medicine suggests that, when such policy is implemented, it can have a significant effect on the use of antimicrobials [99]. For example, a study in Chile showed that regulations banning private retail outlets from supplying antimicrobials without a prescription resulted in a significant reduction in national antimicrobial sales [100].

Discussions with pharmacists and drug sellers in Asia have highlighted indiscriminate antimicrobial sales and raised concerns over poor knowledge on AMR and responsible antimicrobial use [101-103]. Equally, many veterinarians and physicians who are employed directly along the antimicrobial distribution chain are likely to be rewarded with financial incentives for selling particular antimicrobial products [35,101]. Consequently, Sommanustweechai et al. (2018) surmised that inappropriate antimicrobial use by farmers might be linked with this ease of access and inadequate advice for farmers. Similarly, the farmers in the case studies reported a preference for sourcing antimicrobials directly from pharmaceutical companies and retail drug stores. Thus, identifying pharmaceutical companies and pharmacists/drug sellers as a priority audience for education on responsible antimicrobial use practices. The pharmaceutical industry, feed industry, and pharmacy associations need to be engaged in ongoing work to address antimicrobial resistance and AMR in the region.

At present, there is no easy route through which the sale of antimicrobials through retail outlets and pharmacies can be monitored [58]. This present lack of regulation is likely to be corrected with recommendations in-line with the WHO's 20th Model List of Essential Medicines, which would categorize certain classes of medicines including antimicrobials as prescription-only [104]. However, even if such legislation is introduced, there is still a continued need to engage the pharmaceutical supply sector in the message on targeted and responsible antimicrobial use.

Poor awareness of AMR concerns by veterinarians have been identified as a challenge for reducing and optimizing antimicrobial use in LMICs [58,85]. Thus, it is essential that the training and advice of veterinarians and para-veterinarians with regards to responsible antimicrobial use is both harmonized and in-line with international prescribing principles for responsible use such as those promoted by the OIE or WHO $[8,105]$.

\subsection{The Development of the Framework on the Antimicrobial Use/AMR Complex in Livestock}

The case studies present data from a small number of small-scale commercial pig and broiler farms in each country. A convenience sampling method was implemented by in-country collaborators 
and, as such, there is a potential for selection bias [106]. Thus, the results cannot be considered to be representative of national livestock production systems. However, the case study results offer interesting insights into the costs and benefits of antimicrobial use for small commercial producers. There may also be a risk of social desirability bias in the case study results where respondents may report antimicrobial use behaviors that they perceive to be responsible rather than actual practices $[107,108]$. Nonetheless, the results suggest that any such bias is minimal through the detailed responses provided and that farmers' reported opinions do not conform with international guidance on responsible antimicrobial use $[7,56]$. The questionnaire used open questions to try and minimize any social desirability bias by allowing free thought and requiring respondents to propose novel ideas or perceptions not motivated by closed question options [109]. As with the collection of any retrospective data, there is a potential for recall bias. In this context, there was a risk of farmers either under or over reporting antimicrobial use [106]. The training of enumerators for data collection was aimed to minimize this bias by supporting farmers in the recall process such as by using antimicrobial packaging in order to act as a physical reminder.

The bin collection methodology implemented in the Vietnamese case study presented a number of limitations. The farmer was requested to retain all antimicrobial packaging over a six-week period. However, these data were missing for the majority of farms and the farms that did collect packaging frequently collected packaging from non-antimicrobial packaging and did not retain feed labels. Redding et al. (2014) found parallel issues with a lack of understanding by farmers on what constituted an antimicrobial with farmers retaining non-antimicrobial products and disposing of antimicrobial packaging in dairy farms in South America [106]. In addition, the finding that some commercial pig feed labels did not include ingredient listings may have contributed toward inaccurate data collection.

There were issues with collecting a complete set of data from some of the case study farms particularly concerning productivity and economic parameters. Gaps in farm data on productivity and economic costs are a familiar theme across livestock production systems in South East Asia, which limits the scope for conducting detailed analyses into productivity, the financial implications of disease, and the economics of antimicrobial use. Consequently, many of the economic and productivity results reported in the case study are not complete. This issue identifies a hurdle for assessing the effects of any interventions or management changes introduced on farms to reduce antimicrobial use, since, presently, most farms do not collect sufficient productivity data to assess whether such interventions are economically viable.

\section{Materials and Methods}

\subsection{Framing the Antimicrobial Use/AMR Complex in Livestock in South East Asia}

A review of the literature and in-country discussions identified priority livestock sectors, understanding of antimicrobial use and AMR within these sectors, private and public research programs, and the extent of policy support. Pigs and poultry were identified to be the livestock sectors of most economic and social importance across the countries [110]. These sectors provide opportunities to meet the increasing food demand through intensive, integrated, and low-cost production systems. Within these intensive systems, there has been a move toward greater antimicrobial consumption, which has been accompanied with growing concerns for the potential effects on AMR levels in humans, animals, and the environment [5]. Consequently, the following livestock sectors were selected for more detailed investigation into the antimicrobial use/AMR complex.

1. The small-medium commercial broiler sector in Indonesia,

2. The small-medium commercial pig sector in Vietnam,

3. The small-medium commercial pig sector and the larger integrated broiler sector in Thailand. 


\subsection{Case Study Methodology}

Quantitative data relating to the economics of antimicrobials, farm productivity, and farm-level antimicrobial use were collected alongside qualitative information on farmer attitudes to AMR, responsibility, and drivers for antimicrobial use through a face-to-face questionnaire in each country. The questionnaire was designed based on a previous questionnaire study on the drivers into antimicrobial use in the UK pig industry and on information gained from previous Knowledge Attitudes and Practices (KAP) surveys undertaken in the South East Asian region by the FAO [111]. In addition, in Vietnam, the bin collection method was also adopted in which farmers were asked to retain antimicrobial packaging over a six-week period in order to quantify antimicrobial use for a defined period of time [106]. Data collection was undertaken using collaborators within the country. An overview of the case study methodologies used in each country is shown in Table 9.

Table 9. An overview of the materials and methods used to characterize the economics of antimicrobials and describe antimicrobial use behaviors and attitudes to AMR in key livestock sectors in Indonesia, Thailand, and Vietnam.

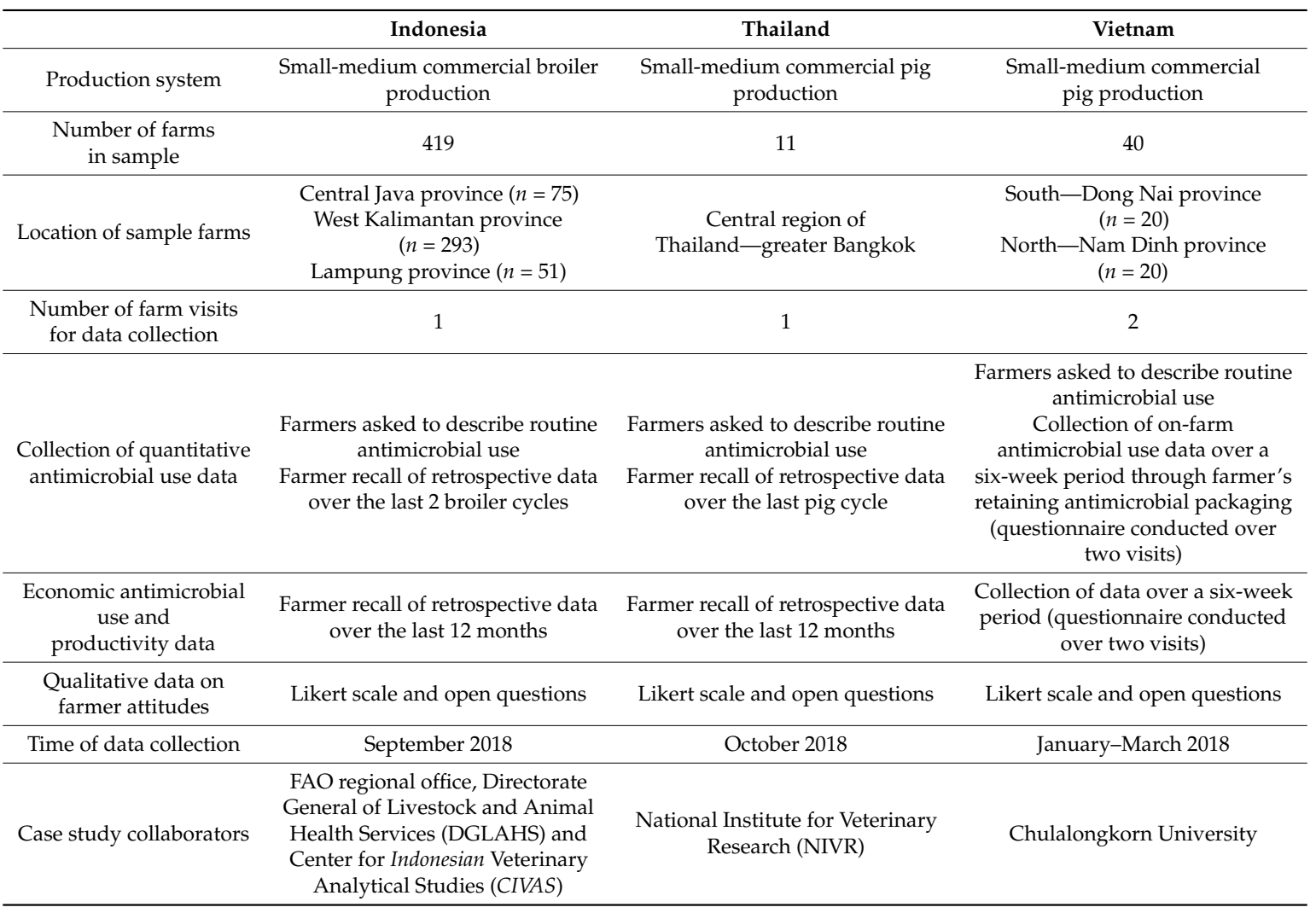

\subsection{Ethical Approval}

Overall ethical approval was granted by the University of Liverpool Veterinary Science Research Ethics Committee, which also required proof of local (country-level) ethical acceptability (Reference number VREC640). In Thailand, the ethical review committee of the department of Health Sciencesfrom Chulalongkorn University granted ethical approval. Since the study did not involve the collection of samples from animals or humans, the research collaborators and local government in Indonesia and Vietnam did not require a specific ethical review. Therefore, documentation mitigating the need for a detailed ethical review was provided from the government livestock departments in each country (Directorate General of Livestock and Animal Health Services (DGLAHS) in Indonesia and National Institute for Veterinary Research (NIVR) in Vietnam). 


\section{Conclusions and Implications for Policy Development}

An overview of the key findings from the framework development to characterize the antimicrobial use/AMR complex in Indonesia, Thailand, and Vietnam and the implications of these conclusions for policy development are presented in Table 10.

Table 10. Key findings and recommendations for policy development and implementation from the development of a framework to characterize the antimicrobial use/AMR complex in livestock systems in Indonesia, Vietnam, and Thailand.

\begin{tabular}{ll}
\hline Priority Area & $\begin{array}{c}\text { Key Findings and Recommendations for Policy Development and Implementation } \\
\text { from the Development of a Framework to Characterize the Antimicrobial } \\
\text { Use/AMR Complex in Livestock Systems in Indonesia, Vietnam, and Thailand }\end{array}$ \\
\hline & $\begin{array}{l}\text { Where there are limited resources, we must focus antimicrobial use and resistance } \\
\text { work on parts of the livestock sector with high potential for animal to human } \\
\text { transmission of AMR. This requires knowledge of the livestock food system and } \\
\text { capacities of the private sector to manage and implement change. }\end{array}$ \\
Study methodology \\
to characterize \\
antimicrobial use
\end{tabular}$\quad \begin{aligned} & \text { Methods to obtain accurate, specific antimicrobial use data in livestock should be } \\
& \text { assessed with the analysis of the relative costs and benefits of obtaining such } \\
& \text { The poultry and pig sector have cycles within and between years that influence } \\
& \text { profitability and, in turn, the economic value of AMU. Therefore, meaningful } \\
& \text { antimicrobial use and resistance economic research should be carried out over a } \\
& \text { number of production cycles. }\end{aligned}$

- The main antimicrobials used are penicillins, tetracyclines, and sulphonamides. Critically important antimicrobials are also frequently used.

Antimicrobial use

- Feed labelling is sometimes misleading and does not list nutritional information or ingredients including antimicrobials added. Therefore, farmers may not know what is contained in commercially-purchased feed.

The economics of antimicrobial use
- The costs of antimicrobials in the production systems are small in total and very small in relation to other costs.

- $\quad$ There is evidence that antimicrobial use in small-scale poultry production systems improves feed conversion ratios and improves overall production.

- $\quad$ The pig industry is susceptible to economic instability with falling prices placing farmers under increasing pressures to minimize costs.

- The poultry industry is also susceptible to economic and market stability, with day-old chick price and availability a constant concern and increasing pressure on commercial feed prices as human food demand increases.

- Small changes in feed prices have big impacts of cycle profitability.
Antimicrobial use and resistance policy for livestock
- $\quad$ During the period of the study, Indonesia, Thailand, and Vietnam have embraced and implemented policies on antimicrobial use control in livestock and AMR surveillance.

- Thailand appears to have the most intensive, modern, and regulated livestock systems with regard to antimicrobial use and more developed policies and implementation such as HP-CIAs requiring and prescription, when compared with Indonesia and Vietnam.

- $\quad$ Thailand has quantified antimicrobial sales using the ESVAC methodology. There is potential for this methodology and approach to be adopted by other LMICs and could be applied to data already collected and supplied to OIE.

- Policy to regulate antimicrobial use should be stepwise with prescription only being the ultimate goal. At present, of the case study countries, Thailand appears to be further along the journey in developing antimicrobial use and resistance policy for livestock than Indonesia or Vietnam. 
A national scheme to promote responsible antimicrobial use in livestock may be a route through which veterinarians and industry stakeholders could be united. This could have an end goal of producing antimicrobial prescribing guidelines for key livestock sectors and advice on alternative methods to prevent disease. Similarly, an independent initiative in the UK has been led by the Responsible Use of Antimicrobials in Animals Alliance (RUMA), which have produced guidelines to support producers in ensuring that antimicrobial use is prudent on livestock farms [112]. Further engagement of veterinarians, independent farmers, livestock production companies, and other key stakeholders is essential if any scheme to promote prudent antimicrobial use is to be successful.

Country-level actions on antimicrobial use should be undertaken with close communications with neighbouring countries as well as at the wider international level. AMR does not respect country borders, which is of particular importance in the South East Asian region where many countries share common borders and have permanent land crossings for importation and exportation. For example, multidrug-resistant Salmonella species have been found to be highly prevalent in pigs, chickens, and their products in the Thailand and the Cambodian border provinces [113].

Country-level actions on antimicrobial use should be undertaken with close communications with neighbouring countries as well as at the wider international level. AMR does not respect country borders, which is of particular importance in the South East Asian region where many countries share common borders and have permanent land crossings for importation and exportation. For example, multidrug-resistant Salmonella species have been found to be highly prevalent in pigs, chickens, and their products in the Thailand and the Cambodian border provinces [113].

In the case study countries, engaging the private sector in policy development and the implementation of the AMR action plan presents a number of challenges. First, there is strong competition between companies in livestock production. Second, there are great concerns by the private sector over the potential economic effects of reducing antimicrobial use and, third, there seems to be little incentive to reduce antimicrobial use in the present climate [114,115]. However, there is increasing international pressure on private as well as public sectors to address AMR and reduce antimicrobial use in livestock. This is also a strategic aim of AMR national action plans. Thailand is an excellent example of where private sector collaborations can be an effective tool for supporting government actions for AMR. This is shown through the work of the AHPA in publishing estimates of antimicrobial consumption in animals. Similar methodology could be applied to other LMICs in South East Asia. The data collected for the OIE report on antimicrobial use in animals is an excellent starting point for exploring antimicrobial sales by sector [62].

While collecting national farm-level antimicrobial data is likely to be a future aspiration, there is still hope to encourage production companies and farmers, through producer organizations, to improve farm recording of key productivity parameters.

Author Contributions: Conceptualization, C.B., W.K., I.P. and J.R. Methodology, investigation, and data curation, R.A., L.C., V.N.G., L.Q.H., I.P., S.J., J.M., J.R., L.S., E.S., A.H.S., J.S., P.T.N. and P.P. Formal analysis, R.A., L.C., I.P. and J.R. Writing-original draft preparation, L.C., I.P. and J.R. Writing-review and editing, L.C., I.P. and J.R. Supervision, C.B., W.K., I.P. and J.R. Dunding acquisition I.P. and J.R.

Funding: University of Liverpool implemented the research on behalf of the Food and Agriculture Organization of the United Nations (LOA/RAP/2017/05) and was part of a larger program of work supported by the United States Agency for International Development (USAID) (OSRO/RAS/502/USA).

Acknowledgments: The authors want to thank the national and local governments for their support in the implementation of the study and to the farmers who generously gave their time during the interviews.

Conflicts of Interest: The authors declare no conflict of interest.

\section{References}

1. Gerland, P.; Raftery, A.E.; Ševčíková, H.; Li, N.; Gu, D.; Spoorenberg, T.; Alkema, L.; Fosdick, B.K.; Chunn, J.; Lalic, N.; et al. World population stabilization unlikely this century. Science 2014, 346, 234-237. [CrossRef] [PubMed] 
2. World Bank Population, Total. The World Bank Data. Available online: https://data.worldbank.org/ indicator/SP.POP.TOTL (accessed on 29 January 2019).

3. Quigley, J.M. Urbanization, Agglomeration, and Economic Development. In Urbanization and Growth; The World Bank Group: Washington, DC, USA, 2009; ISBN 978-0-8213-7573-0.

4. Regmi, A.; Dyck, J. Effects of Urbanization on Global Food Demand. In Changing Structure of Global Food Consumption and Trade; Economic Research Service: Washington, DC, USA, 2001; ISBN 1428940472.

5. Van Boeckel, T.P.; Brower, C.; Gilbert, M.; Grenfell, B.T.; Levin, S.A.; Robinson, T.P.; Teillant, A.; Laxminarayan, R. Global trends in antimicrobial use in food animals. Proc. Natl. Acad. Sci. USA 2015, 112, 5649-5654. [CrossRef]

6. Tackling Drug-Resistant Infections Globally: Final Report and Recommendations. Available online: https: / / amr-review.org/sites/default/files/160525_Finalpaper_withcover.pdf (accessed on 8 January 2019).

7. WHO. World Health Organisation Global Action Plan on Antimicrobial Resistance; The World Health Organization: Geneva, Switzerland, 2015.

8. Aidara-Kane, A.; Angulo, F.J.; Conly, J.M.; Minato, Y.; Silbergeld, E.K.; McEwen, S.A.; Collignon, P.J.; Balkhy, H.; Collignon, P.; Conly, J.; et al. World Health Organization (WHO) guidelines on use of medically important antimicrobials in food-producing animals. Antimicrob. Resist. Infect. Control 2018, 7, 7. [CrossRef] [PubMed]

9. OIE. OIE Terrestrial Animal Health Code. Chapter 6.10. Responsible and Prudent Use of Antimicrobial Agents in Veterinary Medicine; The World Organisation for Animal Health: Paris, France, 2014.

10. FAO. The Food and Agricultural Organisation Action Plan on Antimicrobial Resistance 2016-2020; The Food and Agriculture Organization: Rome, Italy, 2016.

11. Marshall, B.M.; Levy, S.B. Food animals and antimicrobials: Impacts on human health. Clin. Microbiol. Rev. 2011, 24, 718-733. [CrossRef]

12. Antimicrobials in Agriculture and the Environment: Reducing Unnecessary Use and Waste. Available online: https://amr-review.org/sites/default/files/Antimicrobialsinagricultureandtheenvironment--Reducingunnecessaryuseandwaste.pdf. (accessed on 21 January 2019).

13. Tang, K.L.; Caffrey, N.P.; Nóbrega, D.B.; Cork, S.C.; Ronksley, P.E.; Barkema, H.W.; Polachek, A.J.; Ganshorn, H.; Sharma, N.; Kellner, J.D.; et al. Restricting the use of antibiotics in food-producing animals and its associations with antibiotic resistance in food-producing animals and human beings: A systematic review and meta-analysis. Lancet Planet. Health 2017, 1, e316-e327. [CrossRef]

14. Hadjadj, L.; Riziki, T.; Zhu, Y.; Li, J.; Diene, S.M.; Rolain, J.-M. Study of mcr-1 Gene-Mediated Colistin Resistance in Enterobacteriaceae Isolated from Humans and Animals in Different Countries. Genes (Basel) 2017, 8, 394. [CrossRef] [PubMed]

15. Seiffert, S.N.; Hilty, M.; Perreten, V.; Endimiani, A. Extended-spectrum cephalosporin-resistant gram-negative organisms in livestock: An emerging problem for human health? Drug Resist. Updat. 2013, 16, $22-45$. [CrossRef] [PubMed]

16. Moradigaravand, D.; Jamrozy, D.; Mostowy, R.; Anderson, A.; Nickerson, E.K.; Thaipadungpanit, J.; Wuthiekanun, V.; Limmathurotsakul, D.; Tandhavanant, S.; Wikraiphat, C.; et al. Evolution of the Staphylococcus argenteus ST2250 clone in Northeastern Thailand is linked with the acquisition of livestock-associated staphylococcal genes. MBio 2017, 8, 4. [CrossRef] [PubMed]

17. Graveland, H.; Wagenaar, J.A.; Bergs, K.; Heesterbeek, H.; Heederik, D. Persistence of livestock associated MRSA CC398 in humans is dependent on intensity of animal contact. PLoS ONE 2011, 6, e16830. [CrossRef] [PubMed]

18. Patchanee, P.; Tadee, P.; Arjkumpa, O.; Love, D.; Chanachai, K.; Alter, T.; Hinjoy, S.; Tharavichitkul, P. Occurrence and characterization of livestock-associated methicillin-resistant Staphylococcus aureus in pig industries of northern Thailand. J. Vet. Sci. 2014, 15, 529-536. [CrossRef] [PubMed]

19. Zhu, Y.-G.; Johnson, T.A.; Su, J.-Q.; Qiao, M.; Guo, G.-X.; Stedtfeld, R.D.; Hashsham, S.A.; Tiedje, J.M. Diverse and abundant antibiotic resistance genes in Chinese swine farms. Proc. Natl. Acad. Sci. USA 2013, 110, 3435-3440. [CrossRef]

20. Lugsomya, K.; Chatsuwan, T.; Niyomtham, W.; Tummaruk, P.; Hampson, D.J.; Prapasarakul, N. Routine Prophylactic Antimicrobial Use Is Associated with Increased Phenotypic and Genotypic Resistance in Commensal Escherichia coli Isolates Recovered from Healthy Fattening Pigs on Farms in Thailand. Microb. Drug Resist. 2017, 24, 213-233. [CrossRef] [PubMed] 
21. Jans, C.; Merz, A.; Johler, S.; Younan, M.; Tanner, S.A.; Kaindi, D.W.M.; Wangoh, J.; Bonfoh, B.; Meile, L.; Tasara, T. East and West African milk products are reservoirs for human and livestock-associated Staphylococcus aureus. Food Microbiol. 2017, 65, 64-73. [CrossRef] [PubMed]

22. Llor, C.; Bjerrum, L. Antimicrobial resistance: Risk associated with antibiotic overuse and initiatives to reduce the problem. Ther. Adv. Drug Saf. 2014, 5, 229-241. [CrossRef]

23. Aarestrup, F.M. Veterinary drug usage and antimicrobial resistance in bacteria of animal origin. Basic Clin. Pharmacol. Toxicol. 2005, 96, 271-281. [CrossRef] [PubMed]

24. Woolhouse, M.; Farrar, J. Policy: An intergovernmental panel on antimicrobial resistance. Nature 2014, 509, 555-557. [CrossRef]

25. Robinson, T.P.; Bu, D.P.; Carrique-Mas, J.; Fèvre, E.M.; Gilbert, M.; Grace, D.; Hay, S.I.; Jiwakanon, J.; Kakkar, M.; Kariuki, S.; et al. Antibiotic resistance is the quintessential One Health issue. Trans. R. Soc. Trop. Med. Hyg. 2016, 110, 377-380. [CrossRef]

26. Rushton, J. Anti-microbial use in animals: How to assess the trade-offs. Zoonoses Public Health 2015, 62, $10-21$. [CrossRef] [PubMed]

27. Rushton, J.; Bisdorff, B.; Call, D.; Carrique-Mas, J.; Erlacher-Vindel, E.; Gochez, D.; Lees, P.; McMahon, B.; Matthews, L.; Pelligand, L.; et al. An Analysis of the Animal/Human Interface with A Focus on Low-And Middle-Income Countries: Fleming Fund Project to Tackle Global AMR; The World Organisation for Animal Health: Paris, France, 2016.

28. Nhung, N.T.; Cuong, N.V.; Thwaites, G.; Carrique-Mas, J. Antimicrobial Usage and Antimicrobial Resistance in Animal Production in Southeast Asia: A Review. Antibiotics 2016, 5, 37. [CrossRef] [PubMed]

29. World Bank. World Bank Country and Lending Groups-Country Classification; The World Bank: Washington, DC, USA, 2019.

30. Gilbert, M.; Conchedda, G.; Van Boeckel, T.P.; Cinardi, G.; Linard, C.; Nicolas, G.; Thanapongtharm, W.; D'Aietti, L.; Wint, W.; Newman, S.H.; et al. Income disparities and the global distribution of intensively farmed chicken and pigs. PLoS ONE 2015, 112, 5649-5654. [CrossRef] [PubMed]

31. McGlone, J.J. The future of pork production in the world: Towards sustainable, welfare-positive systems. Animals 2013, 3, 401-415. [CrossRef] [PubMed]

32. Pig Production and Marketing in Vietnam. Available online: https://www.angrin.tlri.gov.tw/English/ 2014Swine/p145-152.pdf. (accessed on 9 January 2019).

33. Pig Production in Indonesia. 2014. Available online: https://www.angrin.tlri.gov.tw/English/2014Swine/ p175-186.pdf. (accessed on 9 January 2019).

34. Thanapongtharm, W.; Linard, C.; Chinson, P.; Kasemsuwan, S.; Visser, M.; Gaughan, A.E.; Epprech, M.; Robinson, T.P.; Gilbert, M. Spatial analysis and characteristics of pig farming in Thailand. BMC Vet. Res. 2016, 12, 218. [CrossRef] [PubMed]

35. Dang, P.K.; Saegerman, C.; Douny, C.; Ton, V.D.; Bo, H.X.; Binh, D.V.; Ngan, H.P.; Scippo, M.L. First survey on the use of antibiotics in pig and poultry production in the Red River Delta region of Vietnam. Food Public Health 2013, 3, 247-256.

36. Van Boeckel, T.P.; Thanapongtharm, W.; Robinson, T.; D'Aietti, L.; Gilbert, M. Predicting the distribution of intensive poultry farming in Thailand. Agric. Ecosyst. Environ. 2012, 149, 144-153. [CrossRef] [PubMed]

37. Hidayat, C.; Asmarasari, S.A. Native Chicken Production in Indonesia: A Review. J. Peternak. Indones. 2015, 17, 1-11. [CrossRef]

38. Ipsos Business Consulting. Thailand's Poultry Industry; Ipsos Business Consulting: Bangkok, Thailand, 2013.

39. Wright, T.; Darmawan, B. Indonesia Voluntary Poultry Report; GAIN Report: 1701; United States Department of Agriculture Foreign Agricultural Service: Washington, DC, USA, 2017.

40. Wahyono, N.D.; Utami, M.M.D. A Review of the Poultry Meat Production Industry for Food Safety in Indonesia. J. Phys. Conf. Ser. 2018, 953, 12125. [CrossRef]

41. USAID. Indonesia's Poultry Value Chain. Costs, Margins, Prices, and Other Issues; United States Agency for International Development: Washington, DC, USA, 2013.

42. Preechajarn, S. Poultry and Products Annual Thailand; GAIN Report Number: TH6098; United States Department of Agriculture Foreign Agricultural Service: Washington, DC, USA, 2016.

43. Burgos, S.; Hong Hanh, P.T.; Roland-Holst, D.; Burgos, S.A. Characterization of poultry production systems in Vietnam. Int. J. Poult. Sci. 2007, 6, 709-712. [CrossRef] 
44. Orissa International Pte. Ltd. Poultry Sector in South East Asia Iowa Economic Development Authority; Netflix: Los Gatos, CA, USA, 2017.

45. Souris, M.; Selenic, D.; Khaklang, S.; Ninphanomchai, S.; Minet, G.; Gonzalez, J.P.; Kittayapong, P. Poultry farm vulnerability and risk of avian influenza re-emergence in Thailand. Int. J. Environ. Res. Public Health 2014, 11, 934-951. [CrossRef] [PubMed]

46. Merino, G.; Barange, M.; Blanchard, J.L.; Harle, J.; Holmes, R.; Allen, I.; Allison, E.H.; Badjeck, M.C.; Dulvy, N.K.; Holt, J.; et al. Can marine fisheries and aquaculture meet fish demand from a growing human population in a changing climate? Glob. Environ. Chang. 2012, 22, 795-806. [CrossRef]

47. Report on the Shrimp Sector Asian Shrimp Trade and Sustainability. Available online: http: / / cmsdevelopment.sustainablefish.org.s3.amazonaws.com/2016/04/07/Asian\%20shrimp_long\% 20form-05098e4.pdf (accessed on 14 January 2019).

48. Halim, D.; Juanri, J. Indonesia's Aquaculture Industry: Key Sectors for Future Growth; IPsos: Paris, France, 2016.

49. Belton, B.; Little, D. The Development of Aquaculture in Central Thailand: Domestic Demand versus Export-led Production. J. Agrar. Chang. 2008, 8, 123-143. [CrossRef]

50. Pongsri, C.; Sukumasavin, N. National Aquaculture Sector Overview. Thailand. National Aquaculture Sector Overview Fact Sheets; The Food and Agriculture Organization: Rome, Italy, 2005.

51. Marschke, M.; Betcherman, G. Vietnam's seafood boom: Economic growth with impoverishment? Environ. Dev. Sustain. 2016, 18, 1129-1150. [CrossRef]

52. Goutard, F.L.; Bordier, M.; Calba, C.; Erlacher-Vindel, E.; Góchez, D.; de Balogh, K.; Benigno, C.; Kalpravidh, W.; Roger, F.; Vong, S. Antimicrobial policy interventions in food animal production in South East Asia. BMJ 2017, 358, j3544. [CrossRef]

53. Anon FDA to Limit Use of Colistin to Curb Drug Resistance. National Thailand Portal Available online: http:/ / www.nationmultimedia.com/news/national/30305408 (accessed on 19 January 2019).

54. Thamlikitkul, V.; Rattanaumpawan, P.; Boonyasiri, A.; Pumsuwan, V.; Judaeng, T.; Tiengrim, S.; Paveenkittiporn, W.; Rojanasthien, S.; Jaroenpoj, S.; Issaracharnvanich, S. Thailand Antimicrobial Resistance Containment and Prevention Program. J. Glob. Antimicrob. Resist. 2015, 3, 290-294. [CrossRef] [PubMed]

55. WHO. Critically Important Antimicrobials for Human Medicine-5th Revision 2017; The World Health Organization: Geneva, Switzerland, 2017.

56. MOH. National Action Plan on Antimicrobial Resistance Indonesia 2017-2019; Molina Healthcare: Long Beach, CA, USA, 2017.

57. MARD. National Action Plan for Management of Antibiotic Use ad Control of Antibiotic Resistance in Livestock Production and Aquaculture. Issued in Accordance with Decision No. 2625/QĐ-BNN-TY Dated 21/6/2017 by the Vice Minister of Ministry of MARD; The Ministry of Agriculture and Rural Development: Hanoi, Vietnam, 2017.

58. Sommanustweechai, A.; Chanvatik, S.; Sermsinsiri, V.; Sivilaikul, S.; Patcharanarumol, W.; Yeung, S.; Tangcharoensathien, V. Antibiotic distribution channels in Thailand: Results of key-informant interviews, reviews of drug regulations and database searches. Bull. World Health Organ. 2018, 92, 101-109. [CrossRef] [PubMed]

59. Sommanustweechai, A.; Tangcharoensathien, V.; Malathum, K.; Sumpradit, N.; Kiatying-Angsulee, N.; Janejai, N.; Jaroenpoj, S. Implementing national strategies on antimicrobial resistance in Thailand: Potential challenges and solutions. Public Health 2018, 157, 142-146. [CrossRef]

60. Yamaguchi, T.; Okihashi, M.; Harada, K.; Konishi, Y.; Uchida, K.; Hoang Ngoc Do, M.; Thi Bui, L.; Nguyen, T.D.; Phan, H.B.; Dang Thien Bui, H.; et al. Detection of antibiotics in chicken eggs obtained from supermarkets in Ho Chi Minh City, Vietnam. J. Environ. Sci. Health Part B Pestic. Food Contam. Agric. Wastes 2017, 52, 430-433. [CrossRef] [PubMed]

61. Yamaguchi, T.; Okihashi, M.; Harada, K.; Konishi, Y.; Uchida, K.; Do, M.H.N.; Bui, H.D.T.; Nguyen, T.D.; Nguyen, P.D.; Van Chau, V.; et al. Antibiotic residue monitoring results for pork, chicken, and beef samples in Vietnam in 2012-2013. J. Agric. Food Chem. 2015, 63, 5141-5145. [CrossRef] [PubMed]

62. OIE. OIE Annual Report on the Use of Antimicrobial Agents in Animals Better Understanding of the Global Situation; The World Organisation for Animal Health: Paris, France, 2016.

63. AHPA. Use of Antimicrobial Agents in Veterinary Medicine in Thailand; Animal Health Products Association: Bangkok, Thailand, 2017. 
64. Yusuf, H.; Rukkwamsuk, T.; Idris, S.; Paul, M. Antimicrobial usage surveillance of cattle in Indonesia to address Antimicrobial resistance. In Proceedings of the Advances in Social Science, Education and Humanities Research (ASSEHR), Surabaya, East Java, Indonesia, 1-3 August 2017.

65. CIVAS; FAO. Document and Characterize Antimicrobial Use in Livestock Use in Livestock Sector; The Food and Agriculture Organization: Rome, Italy, 2017.

66. Love, D.C.; Tharavichitkul, P.; Arjkumpa, O.; Imanishi, M.; Hinjoy, S.; Nelson, K.; Nachman, K.E. Antimicrobial use and multidrug-resistant Salmonella spp., Escherichia coli, and Enterococcus faecalis in swine from Northern Thailand. Thai J. Vet. Med. 2015, 45, 43-53.

67. Nhung, N.T.; Van, N.T.B.; Van Cuong, N.; Duong, T.T.Q.; Nhat, T.T.; Hang, T.T.T.; Nhi, N.T.H.; Kiet, B.T.; Hien, V.B.; Ngoc, P.T.; et al. Antimicrobial residues and resistance against critically important antimicrobials in non-typhoidal Salmonella from meat sold at wet markets and supermarkets in Vietnam. Int. J. Food Microbiol. 2018, 2, 301-309. [CrossRef]

68. Zellweger, R.M.; Carrique-Mas, J.; Limmathurotsakul, D.; Day, N.P.J.; Thwaites, G.E.; Baker, S.; Ashley, E.; de Balogh, K.; Baird, K.; Basnyat, B.; et al. A current perspective on antimicrobial resistance in Southeast Asia. J. Antimicrob. Chemother. 2017, 72, 2963-2972. [CrossRef]

69. Rico, A.; Phu, T.M.; Satapornvanit, K.; Min, J.; Shahabuddin, A.M.; Henriksson, P.J.G.; Murray, F.J.; Little, D.C.; Dalsgaard, A.; Van den Brink, P.J. Use of veterinary medicines, feed additives and probiotics in four major internationally traded aquaculture species farmed in Asia. Aquaculture 2013, 412-413, 231-243. [CrossRef]

70. Thi Kim Chi, T.; Clausen, J.; Van, P.; Tersbøl, B.; Dalsgaard, A. Use practices of antimicrobials and other compounds by shrimp and fish farmers in Northern Vietnam. Aquac. Rep. 2017, 7, 40-47. [CrossRef]

71. Phu, T.M.; Phuong, N.T.; Scippo, M.-L.; Dalsgaard, A. Quality of Antimicrobial Products Used in Striped Catfish (Pangasianodon hypophthalmus) Aquaculture in Vietnam. PLoS ONE 2015, 10, 1-8. [CrossRef] [PubMed]

72. Holmström, K.; Gräslund, S.; Wahlström, A.; Poungshompoo, S.; Bengtsson, B.-E.; Kautsky, N. Antibiotic use in shrimp farming and implications for environmental impacts and human health. Int. J. Food Sci. Technol. 2003, 38, 255-266. [CrossRef]

73. Changkaew, K.; Utrarachkiju, F.; Siripanichgon, K.; Nakajima, C.; Suthienkul, O.O.; Suzuki, Y. Characterization of Antibiotic Resistance in Escherichia coli Isolated from Shrimps and Their Environment. J. Food Prot. 2014, 77, 1394-1401. [CrossRef] [PubMed]

74. Okocha, R.C.; Olatoye, I.O.; Adedeji, O.B. Food safety impacts of antimicrobial use and their residues in aquaculture. Public Health Rev. 2018, 39. [CrossRef] [PubMed]

75. Kitiyodom, S.; Khemtong, S.; Wongtavatchai, J.; Chuanchuen, R. Characterization of antibiotic resistance in Vibrio spp. isolated from farmed marine shrimps (Penaeus monodon). FEMS Microbiol. Ecol. 2010, 72, $219-227$. [CrossRef] [PubMed]

76. Sarter, S.; Kha Nguyen, H.N.; Hung, L.T.; Lazard, J.; Montet, D. Antibiotic resistance in Gram-negative bacteria isolated from farmed catfish. Food Control 2007, 18, 1391-1396. [CrossRef]

77. Rico, A.; Van den Brink, P.J. Probabilistic risk assessment of veterinary medicines applied to four major aquaculture species produced in Asia. Sci. Total Environ. 2014, 468-469, 630-641. [CrossRef] [PubMed]

78. Little, D.; Edwards, P. Integrated Livestock-Fish Farming Systems; The Food and Agriculture Organization: Rome, Italy, 2003.

79. Koeypudsa, W.; Yakupitiyage, A.; Tangtrongpiros, J. The fate of chlortetracycline residues in a simulated chicken-fish integrated farming systems. Aquac. Res. 2005, 36, 570-577. [CrossRef]

80. Carrique-Mas, J.J.; Rushton, J. Integrated interventions to tackle antimicrobial usage in animal production systems: The ViParc project in Vietnam. Front. Microbiol. 2017, 8, 1062. [CrossRef] [PubMed]

81. Pan, C. Pork Quarterly Q4 2017. Steady Growth in Production Brings Trade into Sharper Focus; Rabobank: Utrecht, The Netherlands, 2017.

82. McCracken, C. Pork Quarterly Q2 2018. Uncertainties Threaten Optimism in Global Pork Trade; Rabobank: Utrecht, The Netherlands, 2018.

83. Economics of Closed Versus Open Broiler Houses in West Java. Available online: https: / / www.difslive.com/wp-content/uploads/2017/06/Economics-of-closed-broiler-house-versusopen-house-in-West-java-june2017-def.pdf (accessed on 29 January 2019).

84. Sherrad, J.; Cordingley, B. Global Animal Protein Outlook 2018; United States Department of Agriculture: Washington, DC, USA, 2017. 
85. Schar, D.; Sommanustweechai, A.; Laxminarayan, R.; Tangcharoensathien, V. Surveillance of antimicrobial consumption in animal production sectors of low- and middle-income countries: Optimizing use and addressing antimicrobial resistance. PLoS Med. 2018, 15, e1002521. [CrossRef] [PubMed]

86. Van Cuong, N.; Nhung, N.T.; Nghia, N.H.; Mai Hoa, N.T.; Trung, N.V.; Thwaites, G.; Carrique-Mas, J. Antimicrobial Consumption in Medicated Feeds in Vietnamese Pig and Poultry Production. Ecohealth 2016, 13, 490-498. [CrossRef]

87. Nguyen, N.T.; Nguyen, H.M.; Nguyen, C.V.; Nguyen, T.V.; Thwaites, G.; Ngo, H.T.; Baker, S.; Carrique-Mas, J.; Nguyen, M.T.; Thai, H.Q.; et al. Use of colistin and other critical antimicrobials on pig and chicken farms in southern Vietnam and its association with resistance in commensal Escherichia coli bacteria. Appl. Environ. Microbiol. 2016, 82, 3727-3735. [CrossRef]

88. Mills, G. Ban must be enforced on preventive antibiotics. Vet. Rec. 2018, 183, 612 LP-612.

89. Karavolias, J.; Salois, M.J.; Baker, K.T.; Watkins, K. Raised without antibiotics: Impact on animal welfare and implications for food policy. Transl. Anim. Sci. 2018, 2, 337-348. [CrossRef]

90. Macan-Markar, M. Shakeup in Thai poultry industry as human health fears grow. Nikkei Asian Rev. 2017.

91. Maron, D.F.; Smith, T.J.S.; Nachman, K.E. Restrictions on antimicrobial use in food animal production: An international regulatory and economic survey. Global. Health 2013, 16, 48. [CrossRef] [PubMed]

92. Ben Lagha, A.; Haas, B.; Gottschalk, M.; Grenier, D. Antimicrobial potential of bacteriocins in poultry and swine production. Vet. Res. 2017, 48. [CrossRef] [PubMed]

93. Buller, H.; Hinchcliffe, S.; Hockenhull, J.; Barrett, D.; Reyher, K.; Butterworth, A.; Heath, C. Systematic Review and Social Research to Further Understanding of Current Practice in the Context of Using Antimicrobials in Livestock Farming and to Inform Appropriate Interventions to Reduce Antimicrobial Resistance within the Livestock Sector; Department for Environment Food and Rural Affairs: London, UK, 2015.

94. Coyne, L.A.; Latham, S.M.; Williams, N.J.; Dawson, S.; Donald, I.J.; Pearson, R.B.; Smith, R.F.; Pinchbeck, G.L. Understanding the culture of antimicrobial prescribing in agriculture: A qualitative study of UK pig veterinary surgeons. J. Antimicrob. Chemother. 2016, 71, 3300-3312. [CrossRef] [PubMed]

95. AgersoØ, Y.; Aarestrup, F.M. Voluntary ban on cephalosporin use in Danish pig production has effectively reduced extended-spectrum cephalosporinase-producing Escherichia coli in slaughter pigs. J. Antimicrob. Chemother. 2013, 68, 569-572. [CrossRef] [PubMed]

96. De Briyne, N.; Atkinson, J.; Borriello, S.P.; Pokludov, L. Antibiotics used most commonly to treat animals in Europe. Vet. Rec. 2014, 175, 325. [CrossRef]

97. BPC. British Poultry Council Antibiotic Stewardship Report; Botswana Power Corporation: Palapye, Botswana, 2017.

98. Merrett, G.L.B.; Bloom, G.; Wilkinson, A.; MacGregor, H. Towards the just and sustainable use of antibiotics. J. Pharm. Policy Pract. 2016, 9, 31. [CrossRef]

99. Bebell, L.M.; Muiru, A.N. Antibiotic use and emerging resistance: How can resource-limited countries turn the tide? Glob. Heart 2014, 9, 347-358. [CrossRef]

100. Bavestrello, L.; Cabello, A.; Casanova, D. Impact of regulatory measures in the trends of community consumption of antibiotics in Chile. Rev. Med. Chile 2002, 130, 1265-1277. [CrossRef]

101. Mao, W.; Vu, H.; Xie, Z.; Chen, W.; Tang, S. Systematic review on irrational use of medicines in China and Vietnam. PLoS ONE 2015, 10, e0117710. [CrossRef] [PubMed]

102. Miller, R.; Goodman, C. Performance of retail pharmacies in low- and middle-income Asian settings: A systematic review. Health Policy Plan. 2016, 31, 940-953. [CrossRef] [PubMed]

103. Nga, D.T.T.; Chuc, N.T.K.; Hoa, N.P.; Hoa, N.Q.; Nguyen, N.T.T.; Loan, H.T.; Toan, T.K.; Phuc, H.D.; Horby, P.; Van Yen, N.; et al. Antibiotic sales in rural and urban pharmacies in northern Vietnam: An observational study. BMC Pharmacol. Toxicol. 2014, 15, 6. [CrossRef] [PubMed]

104. WHO. The Selection and Use of Essential Medicines Report of the WHO Expert Committee on Selection and Use of Essential Medicines, 2017 (including the 20th WHO Model List of Essential Medicines and the 6th WHO Model List of Essential Medicines for Children) (March 2017); The World Health Organization: Geneva, Switzerland, 2017.

105. OIE. Responsible and Prudent Use of Antimicrobial Agents in Veterinary Medicine; The World Organisation for Animal Health: Paris, France, 2016.

106. Redding, L.E.; Cubas-Delgado, F.; Sammel, M.D.; Smith, G.; Galligan, D.T.; Levy, M.Z.; Hennessy, S. Comparison of two methods for collecting antibiotic use data on small dairy farms. Prev. Vet. Med. 2014, 114, 213-222. [CrossRef] 
107. Bowling, A. Mode of questionnaire administration can have serious effects on data quality. J. Public Health 2005, 27, 281-291. [CrossRef] [PubMed]

108. Foddy, W.; Mantle, J. Constructing Questions for Interviews and Questionnaires-Theory and practice in social research. Physiotherapy 1994, 80, 382. [CrossRef]

109. O'Cathain, A.; Thomas, K.J. Any other comments? Open questions on questionnaires-A bane or a bonus to research? BMC Med. Res. Methodol. 2004, 4, 25. [CrossRef] [PubMed]

110. OECD. OECD Data: Meat Consumption; The Organisation for Economic Co-operation and Development: Paris, France, 2018.

111. Coyne, L.A.; Latham, S.M.; Dawson, S.; Donald, I.J.; Pearson, R.B.; Smith, R.F.; Williams, N.J.; Pinchbeck, G.L. Antimicrobial use practices, attitudes and responsibilities in UK farm animal veterinary surgeons. Prev. Vet. Med. 2018, 161, 115-126. [CrossRef] [PubMed]

112. UK 5 Year Antimicrobial Resistance (AMR) Strategy. Action Plan for the Responsible Use of Medicines in Agriculture Alliance (RUMA) and Its Individual Members. Available online: https:/ / www.ruma.org.uk/wpcontent/uploads/2015/08/2015-04RUMA-Action-Plan-for-implementing-the-UK-5-Year-AMR-stra.pdf (accessed on 11 January 2019).

113. Trongjit, S.; Angkititrakul, S.; Tuttle, R.E.; Poungseree, J.; Padungtod, P.; Chuanchuen, R. Prevalence and antimicrobial resistance in Salmonella enterica isolated from broiler chickens, pigs and meat products in Thailand-Cambodia border provinces. Microbiol. Immunol. 2017, 61, 23-33. [CrossRef]

114. World Bank. Drug-Resistant Infections: A Threat to Our Economic Future; World Bank Report: Washington, DC, USA, 2016.

115. Nurtini, S.; Muzayyanah, F.; Mujtahidah, A.; Haryadi, T.; Hakim, A. Performance of Broiler Farmer in Partnerships System at Surakarta, Indonesia. J. Adv. Agric. Technol. 2017, 4, 192-195. [CrossRef]

(C) 2019 by the authors. Licensee MDPI, Basel, Switzerland. This article is an open access article distributed under the terms and conditions of the Creative Commons Attribution (CC BY) license (http:/ / creativecommons.org/licenses/by/4.0/). 